\title{
Indigenous Peoples and the Capitalist World System: Researching, Knowing, and Promoting Social Justice
}

\author{
Asafa Jalata \\ University of Tennessee, Knoxville, USA \\ Email: ajalata@utk.edu
}

Received January $19^{\text {th }}, 2013$; revised February $23^{\text {rd }}, 2013$; accepted March $4^{\text {th }}, 2013$

\begin{abstract}
Copyright (c) 2013 Asafa Jalata. This is an open access article distributed under the Creative Commons Attribution License, which permits unrestricted use, distribution, and reproduction in any medium, provided the original work is properly cited.
\end{abstract}

\begin{abstract}
This paper explores the major consequences of the expansion of the European-dominated capitalist world system, colonial terrorism, and continued subjugation for indigenous Americans, Australians, and Africans between the late fifteenth and nineteenth centuries. Western powers as well as most of the descendants of European colonialists in Europe, the Americas, Australia, and in Africa and their regional and local collaborators deny or forget or minimize the crimes committed against indigenous peoples and claim that their ancestors spread modernity and civilization around the world. Not recognizing these crimes and ignoring or forgetting or minimizing them have far reaching consequences for humanity and raise moral and ethical issues for the validity of modern civilization that claims to promote the principles of the United Nations' Universal Declaration of Human Rights, democracy, and social justice. The commitment to these principles and truly promoting them require reevaluating the past and present mistakes in the modern world system to openly and honestly debate them and seek correct and urgent solutions for the surviving indigenous peoples who are still suffering from state terrorism, massive human rights violations, dispossession of resources and rights, absolute poverty, disease, and illiteracy.
\end{abstract}

Keywords: Indigenous Peoples; Global Capitalism; Colonialism; State Terrorism; Genocide; Dispossession; Social Justices; Human Rights Violations, Indigenous Movements; Human Rights

\section{Introduction}

The paper critically and thoroughly examines how indigenous peoples have been terrorized, exterminated, abused, and misused by those ethno-nations that control nation-states in the capitalist world system. The homelands, economic and natural resources of indigenous peoples were expropriated and transferred to colonial settlers and their descendants and collaborators that have no interest to protect the political, economic, civil, and social rights that are articulated in the United Nations' Universal Declaration of Human Rights and the Rights of Indigenous Peoples. Since indigenous peoples are not represented in academic and media institutions, their voices are muzzled and hidden and most people are misinformed and know nothing or little about them. By degrading and erasing the cultures, histories, and humanity of indigenous peoples, the settlers and their scholars have convinced themselves that they could/can terrorize, annihilate, and dispossess the resources of these peoples without moral/ethical and political responsibilities. Specifically, the Euro-American hegemonic scholarship has treated indigenous peoples as objects rather than subjects of history. Consequently, this scholarship has produced "false" knowledge, instead of "objective" one about indigenous peoples. The world hegemonic knowledge because of its rejection of multi-cultural forms of knowledge and wisdoms and its abyssal thinking tradition has failed to recognize the humanity of indigenous peoples and their perspectives and their movements for social justice.

The piece attempts to inform the world community about the plight of these stateless peoples and to search for ways of implementing universal human rights and rights of indigenous peoples by supporting their respective social justice movements. For almost two decades, I have researched and explored the relationship between the colonization and incorporation of the indigenous Oromo people and their homeland, Oromia, into the Ethiopian Empire and the racialized global capitalist system and the development of the Oromo national movement. Later I have extended my research beyond Oromia, Ethiopia, and included Sudan and the broader geopolitical region and sociocultural area of North-East Africa. Gradually I have begun to study about the conditions of indigenous peoples in the larger African continent, the Americas, Australia, and Asia to understand why the indigenous peoples in these continents were colonized, terrorized, victimized, and almost destroyed by Euro-American colonial forces and their collaborators that have racialized the capitalist world system through the violation of human rights and the denial of democracy and social justice.

\section{European Colonialism and Injustices}

The Euro-American colonial powers used their superior military forces, weapons, and collaborators to enslave and colonize 
directly or indirectly pre-capitalist societies around the world to exploit their economic resources and labor power through looting, piracy, terrorism, genocide, expropriation, annexation, and continued subjugation. Consequently, the original accumulation of wealth/capital occurred in the West; this accumulated capital gradually facilitated the transformation of mercantilism into industrial capitalism and the expansion of the Industrial Revolution in the eighteenth and nineteenth centuries and increased the demand for raw materials, free or cheap labor (mainly slaves), markets, and the intensification of global colonial expansion in the world (Marx, 1967; Rodney, 1972). With the development of global capitalism, further division of labor, the advancement of technology and organization capacity in the form of state, the interstate system, and the transnational corporation, and with the limitless capacity to accumulate more capital in a globalized world, certain human groups have demonstrated their capabilities to impose their power on other human groups through colonialism that has involved war, terrorism, and genocide. According to Bernard Magubane (1979: p. 3 ), "While colonialism has an ancient history, the colonialism of the last five centuries is closely associated with the birth and maturation of the capitalist socioeconomic system. The pursuit and acquisition of colonies, their political and economic domination, accompanied the mercantile revolution and the founding of capitalism."

The colonizing nations of the West and their collaborators had justified "their scramble for foreign territories as fulfillment of a sacred duty to spread their form of civilization to the world" (Bodely, 1982: p. 12). These countries used the discourses of the superiority of their race, culture, civilization, and Christian religion to promote and justify destructive and exploitative policies, such as terrorism, genocide, and economic exploitation. John H. Bodely (1992: p. 37) characterizes the genocide and ethnocide committed by such nation-states as "an immense human tragedy". The more Euro-Americans advanced in technology and organizational capacity, the more they engaged in terrorism and genocide in order to satisfy their group and individual economic interests. As we shall see below, European countries, such as Spain, Portugal, England, France, Holland, Germany, Italy, and Belgium started capitalist colonial expansion to the Americans, Africa, Australia and Asia through engaging in terrorism, genocide, and gross human rights violations and at the same time claimed the superiority of their cultures, religion (Christianity), race, and civilization. The development of capitalism with its political structures, such as nation-states, enabled European colonialists to expand and commit terrorism and genocide so that they could extract resources. According to Elizabeth Colson (1992: p. 278), "Economic systems have emerged that created massive conflicts of interests between classes and also nations. Technologies empower those who are able to seize control of the state apparatus and enhance the stakes for which people contend... [and] the further creation of technologies that enable humans to play with destructive emotions and habituate themselves to violence under conditions that give them the pleasure of terror without expectation that it will recoil upon them."

Mainstream social scientists of the nineteenth century justified "a deliberate and violent political act carried out as national policy in order to gain access to the natural resources controlled by" indigenous peoples, and "espoused 'scientific' evolutionary theories that explained the destruction and suggested that it was inevitable" (Bodley, 1992: p. 38). Terrorism as an instrument of massive violence to terrorize indigenous peoples emerged with the racialized capitalist world system. It was practiced through colonialism, servitude, and racial slavery in order to transfer the resources of the indigenous peoples to European colonialists and their descendants. Most of those indigenous peoples that survived terrorism and genocide were reduced to the status of slavery or semi-slavery (see De Las Casas, 1992). Under the guise of "scientific" theories, most Western scholars have justified the destruction of indigenous peoples; they have made "scientific" claims to justify the gross human rights violations and to promote Euro-American personal and group interests at the cost of the indigenous peoples. Accepting ideologically and culturally blind thinking has prevented most of these scholars, colonialists, their descendants, and their collaborators from critically understanding the meaning and consequences of colonial terrorism and other crimes against humanity. Still Universities around the world ignore these issues and mainly disseminate the knowledge for domination and exploitation at the cost of the stateless peoples.

The processes of expropriation, racial slavery, and colonialism resulted in hierarchical organization of world populations through the creation of an elaborate discourse of race or racism (Jalata, 2001). "A racial project is simultaneously an interpretation, representation or explanation of racial dynamics", Howard Winant (1994: p. 24) writes, "and an effort to organize and distribute resources along particular racial lines" (author's emphasis). Simply put, racism is an expression of institutionalized patterns of colonizing structural power and social control in order to transfer labor and economic resources from the powerless to the powerful group. By inventing nonexistent races, the racist ideology institutionalizes "the hierarchies involved in the worldwide division of labor" (Balibar \& Wallerstein, 1991: p. 6). Race and racism are socio-political constructs since all human groups are biologically and genetically more alike than different (Malik, 1996). To justify racial slavery and colonialism, the ideology of racism was developed in scientific and religious clothing and matured during the last decades of the nineteenth and the beginning of the twentieth centuries. Understanding of these issues is necessary to correctly address the problems of racism and other injustices in the world. The global process of racial/ethno-national inequality started through establishing settler colonialism, practicing terrorism and genocide, and intensifying two types of labor recruitment systems: wage labor for poor whites and coerced labor for enslaved non-whites (Roediger, 1991; Jalata, 2001). The White Anglo-Saxon Protestant groups that initially dominated the world through the capitalist system developed two major social stratification systems: class and racial caste systems (Du Bois, 1977 [1935]).

While the class system and gender hierarchy were maintained to protect the power of rich white males in an emerging white societies, the racial caste (i.e., racial slavery and segregation) was invented to keep indigenous and enslaved peoples at the bottom of white societies so that they would provide their labor and other resources freely or cheaply. As the ideology of whiteness was invented and used to exterminate Native Americans and to transfer their resources to white society, it was also used to explain and justify racial slavery and segregation. The settlers conveniently invented "Indian savagery" through the ideology of whiteness and committed genocide on indigenous Americans (Roediger, 1991) and other indigenous peoples. Although many authors explained the role of colonial violence in the Americas and in other continents, they did not explore the 
connections among capitalist incorporation, various forms of violence, and colonial terrorism. Competing European colonial forces engaged in state-sponsored terrorism that was practiced in forms of unjustified wars, organized and systematic mass killings, mutilation and trophy taking, ecological and cultural destruction, and spreading of lethal diseases and continued subjugation. By engaging in such crimes against humanity, the European colonial forces had laid the foundations for the economic and political supremacy of North America and Western Europe in the global capitalist world system. The terrorist attacks on the life and liberty of indigenous peoples by EuroAmerican colonial powers and their collaborators also destroyed existing institutions and economies and exposed the conquered peoples to poverty and famine-induced "holocausts" (Davis, 2001).

The destruction of indigenous cultures and institutions resulted in massive deaths (Polanyi, 1944: pp. 159-160). Ruth Blakeley (2009: p. 55) notes that the European colonial powers used various forms of coercion including state terrorism in their acquisition of territories and establishing their colonial institutions; these powers terrorized the indigenous populations and forced them "into supplying conquerors with food supplies, threatening them with death if they did not acquiescence, and the wiping out of whole [cultural groups] that were deemed of no use to the economic projects of the European settlers. Those that did survive were terrorized into forced labor, often as slaves". Most Euro-American scholars and institutions intentionally distorted the humanity, cultures, and civilizations of the indigenous peoples to justify colonial violence, cultural destruction, and continued subjugation (Wilson, 1997; Josephy, 1991). Those few scholars, such as R. Brian Ferguson and Neil L. Whitehead (1992) and Eric Wolf (1981) who have tried to explain the impact of colonial violence on indigenous peoples did not go far enough to explain the essence and consequences of colonial terrorism.

\section{Indigenous Americans and Their Victimization}

The complex processes of incorporation of indigenous Americans started when Queen Isabel and King Ferdinand of Spain granted Christopher Columbus on April 17, 1492 the privilege of exploring, colonizing, and plundering the Indies by financing his expeditions. The monarchs appointed Columbus as the Admiral of the Ocean Sea, promising him 10 percent of the profits from gold and spices he would bring back, and to appoint him as a governor over new areas he would colonize (Zinn, 2003: p. 2). Consequently, Columbus with his associates engaged in four voyages to the Americas. When they first arrived, "the Spaniards were favorably received and entertained by the Arawak people, who traded food and water and a few gold ornaments for such trifles as newly minted copper coins, brass bells and even bits of broken glass and pottery" (Cohen, 1969: pp. 17-18). Columbus called the Indies "the earthly Paradise" (Cohen, 1969: p. 19); he explained that the Arawak had primitive weapons made of sticks, and also mentioned that the people were obedient and willing to give what they owned (Cohen, 1969: pp. 17-118). The Arawak people without knowing with what kind people they were dealing provided the Spaniards with meals of boiled roots and with everything they asked freely. Realizing that the Arawak could not defend their homeland from the invading Spaniards, Columbus wrote a letter to the monarchs of Spain stating that "I found very many islands with large populations and took possession of them all for their Highnesses; this I did by proclamation and unfurled the royal standard. No opposition was offered" (Cohen, 1969: p. 115).

The Spaniards characterized one of the indigenous groups called the Caribs cannibals and singled out for annihilation (Josephy, 1991: p. 3). The Caribs suffered in the hands of the Spaniards: "Some of the Caribs survived 'the terrible five-century American Indian holocaust' and 'commencing with Columbus' arrival among them, Spanish, French, and English invaders, colonizers, pirates, and imperial exploiters all but exterminated them, slaughtering Caribs wholesale with fire, steel, European torture, and wiping out their settlements with the pox, measles, diphtheria, and other white men's diseases to which the Indians had no resistance" (Josephy, 1991: p. 3). The Spaniards imposed terror on the people they encountered to frighten the surrounding peoples in order to reduce their will to resist Spanish colonialism. To prove the profitability of his expeditions to his sponsors, Columbus frequently sent cargoes of gold, other valuables, and slaves to Spain that he obtained through terrorizing the indigenous Americans. Since his main goal was to obtain gold, Columbus captured some indigenous peoples as soon as he arrived in the Indies to collect information from them on the sources of gold (Zinn, 2003: p. 2). This first expedition set the stage for "the racism and savagery of the world conquest" (Chomsky, 1993: p. 5). The arrival of Columbus and his sailors in the Indies had gradually brought disaster and violence including colonial terrorism to the peaceful and generous indigenous peoples (Blakeley, 2009: pp. 56-57).

At the beginning of Columbus' second expedition, on May 4, 1493, through his "Bull of Donation", Pope Alexander VI of Rome granted all lands occupied and would be colonized in the Americas and the Orient by Christopher Columbus and not already occupied by any Christian king or prince as of Christmas 1492 to the Catholic monarchs of Isabel and Ferdinand (Shiva, 1997: p. 1). Columbus established the first colony early in 1494 on the island of Hispaniola (now Haiti and the Dominican Republic), and collected a sizable amount of gold and shipped back to Spain. He and his associates continued to use terrorism to obtain more food, gold, women, slaves, and lands. In 1495, the Spaniards went from island to island taking indigenous Americans as captives and taking women and children as slaves for sex and labor (Zinn, 2003: p. 4). The Spaniards built seventeen towns on the island of Hispaniola by 1515 , and began to enslave indigenous peoples who welcomed them innocently and forced them to work on mining of gold and silver and agriculture to grow crops, cotton, and sugar cane; in almost two decades "their population on this fertile island had shrunk from a quarter of a million to fourteen thousand; in a few more years they had become extinct" (Debo, 1995: pp. 19-20). As we shall see below, the Spaniards and other various European groups continued these projects of terrorism and slavery and the process of cultural destruction and genocide or continued subjugation for several centuries. Although "it is beyond human capacity to compile an accurate log of the murder, cruelty, false imprisonment and other crimes committed" (De Las Casas, 1992: p. 37), let me briefly explain the anatomy of colonial terrorism in the Indies.

The Spaniards used the strategy of terrorism "in all lands they invaded: to stage a bloody massacre of the most public possible kind in order to terrorize those meek and gentle people" (De Las Casas, 1992: p. 45). As Bartolomé De Las Casas (1992: p. 13) testifies, "the indigenous peoples never did the 
Europeans any harm whatever; on the contrary, they believed them to have descended from the heavens, at least until they or their fellow-citizens had tasted, at the hands of these oppressors, direct robbery, murder, violence, and all other manner of trials and tribulations." The colonial settlers and their descendants raped indigenous women for perpetuating terrorism and sexual gratification. "The serial rape of captive Indian women became ritualized public spectacles at ... trade fairs," Ned Blackhawk (2006: p. 77) writes, "bringing the diverse male participants... together for the violent dehumanization of Indian women." The use of sexual violence is a tactic of terror and genocide (Sharlack, 2002: p. 107)." When the Indians saw Spanish men building houses and villages to settle on their land without asking permission," De Las Casas (1971: p. 121) comments, "as if it belonged to them, and knowing how in opportune the Spanish were with their demands, as well as how they had forced other Indians to sail with them, they took the news of the settling very badly." As the indigenous peoples refused to supply food and labor for the Spaniards, the latter intensified the use of various forms of violence and intimidation. Practically "every Spaniard went out among the Indians robbing and seizing their women wherever he pleased, and doing them such injuries that the Indians decided to take vengeance on any Spaniards they found isolated or unarmed" and killed some of them (Cohen, 1969: p. 187).

The Spaniards also used the strategy of divide and conquer policy by recruiting and mobilizing the warriors of one indigenous group against the other to facilitate mutual self-destruction (Hall, 1989: p. 68). Consequently, various indigenous warriors enslaved and merchandized their war captives while collaborating with competing European colonial powers (Whitehead 1992: p. 138). In addition to colonial terrorism and the strategy of divide and conquer, "the introduction of new pathogens was probably the single most dramatic source of change in Indian Society, within a century reducing native population to about one-tenth of its former extent" (Hall, 1989: p. 71). Furthermore, the destruction of indigenous ecosystems, "germ colonization", warfare, slavery, famine, and alcoholism dramatically depopulated indigenous peoples (Dunaway, 1996: p. 362). The Spaniards moved from places to places by destroying the indigenous Americans through employing several tactics: one of these tactics was torture. As Blakeley (2009: p. 228) states, torture can be a tool of terrorism "carried out by representatives of the state against civilians to instill fear for political purposes." They aimed always at inspiring terror by their cruelties; one time they "built a long gibbet, low enough for the toes to touch the ground and prevent strangling, and hanged thirteen [indigenous Americans]... When the Indians were thus still alive and hanging, the Spaniards tested their strength and their blades against them, ripping chests open with one blow and exposing entrails... Then, straw was wrapped around their torn bodies and they were burned alive" (De Las Casas, 1971: p. 121).

The Spaniards first focused on establishing their colonial settlements in the Greater Antilles that led to the decimation of the indigenous people by warfare, diseases, and slavery or forced labor. After 1620, the Lesser Antilles became the contested area for colonization by the French, Dutch, and English and other European groups. Ricardo Alegría (1997: p. 12) asserts that the Spaniards "eagerness to impose their religion and to obtain the greatest possible profits, were far from scrupulous in their treatment of the natives. Indeed, their cruelty hastened the disintegration of the native culture and its eventual annihilation.
By 1510 the Indian population of the islands was almost totally extinct, and colonizers had to import natives from South America to work in the Antillean gold mines." The Spaniards killed young boys and girls and cut their arms and legs into chunks and fed their dogs. As De Las Casas (1992: p. 125) notes, the Spaniards "ensure that wherever they travel they always have a ready supply of natives, chained and herded like so many calves on the hoof. These they kill and butcher as the need arises. Indeed, they run a kind of human abattoir or flesh market, where a dog-owner can casually ask, not for a quarter of pork or mutton, but for 'a quarter of one of those likely lads over there for my dog,' and undertake to repay the debts when he has 'killed another blackguard for myself'."

These colonialists hunted down with dogs and killed those who tried to flee or they hanged or burned to death those indigenous peoples who showed the sign of resistance to Spanish settler colonialism. Due to the cruelty and inhumane behavior of the Spaniards resistance took different forms. "Among the Arawaks, mass suicide began, with cassava poison. Infants were killed to save them from the Spaniards. In two years, through murder, mutilation, or suicide, half of the 250,000 Indians on Haiti were dead" (Zinn, 2003: pp. 4-5). When the settlers exhausted the exploitation of gold, they began to use the indigenous peoples as slave labor on agriculture (Zinn, 2003: p. 5). De Las Casas (1992: p. 13) provides vivid description of the anatomy of the terrorism imposed by the Spaniards on the Indies to obtain gold and other valuables: "The reason the Christians have murdered on such a vast scale and killed anyone and everyone in their way is purely and simply greed. They have set out to line their pockets with gold and to amass private fortune as quickly as possible so that they can then assume a status quite at odds with that into which they were born.” By 1542 the colonizers killed more than twelve million people in the Caribbean, Mexico, and Central America (Kiernan, 2007: p. 77). To impose terror and fear on the surrounding population groups, the Spaniard started flogging, beating, thrashing, punching, burning alive, cutting the legs or hands off, burning and roasting them alive, butchering babies and feeding dogs, and throwing them to wild dogs.

In the processes, the Spanish settlers had lost their own humanity and "had become so anaesthetized to human suffering by their own greed and ambition that they had ceased to be men in any meaningful sense of the term and had become, by dint of their own wicked deeds, so totally degenerated and given over to a reprobate mind" (De Las Casas, 1992: p. 3). The Spaniards burned people alive or cut them to pieces or tortured them or killed them by swords. Slavery was also a major cause for the death of some of the indigenous peoples. Men were separated from their wives and communities to work the soil or to mine gold; they were not allowed to take care of their families and communities. Similarly, mothers overworked and famished and had no milk; consequently, their newly born babies perished. Beginning from 1514, the Spaniards developed a new policy known as a repartimiento after annihilating most of the indigenous peoples; they divided the lands of the indigenous peoples and the survivors were forced to work as semi-slaves in encomienda. "The settlers put men to work in gold mines and sent women 'into the fields of the big ranches to hoe and till the land,' preventing them from cohabiting and having children. Men and women died 'from the same causes, exhaustion and hunger.' Cruelty, violent greed, and the imposition of agricultural serfdom all took their continuing genocidal toll" (Kiernan, 
2007: p. 86)

The indigenous of Central America were hunting and agricultural communities with a few complex empires such as Aztec and Inca. The Inca monarch with his army of 80,000 soldiers confronted "the Spanish conquistador Francisco Pizzarro at the Peruvian highland town of Cajamarca on November 16, 1532" (Diamond, 1999: p. 68). This powerful monarch was only defeated because of the Spaniards' superior weapons. Various Spanish forces continued to terrorize and extract economic resources of the indigenous Americans. Specifically the Spanish merchants and landlords from Spain who were interested in gold to make money financed the expedition of Hernando Cortés. To fulfill his own objective and the goal of these merchants and landlords "Cortés... began his march of death from town to town, using deception, turning Aztec against Aztec, killing with the kind of deliberateness that accompanying a strategy - to paralyze the will of the population by a sudden frightful deed" (Zinn, 2003: p. 11). Hernan Cortés with an army of 400 started his "spectacularly brutal campaign" to colonize Mexico in April 1519 with the help of his coastal native allies; he first attacked and terrorized the kingdom of Anahuac and its capital, Tenochtitlan. His army and his indigenous allies annihilated the Otomi people by lancing, stabbing and shooting them with iron bolts, crossbows, and guns (Kiernan, 2007: p. 88). "Heavily armed columns of troops devastated the most populous islands and destroyed the most powerful kingdom of the New World, dispatched massive quantities of plunder back to the Old [Continent], opened up the Americas to other European powers and settlers, and established grim new precedents for their murder of indigenous peoples" (Kiernan, 2007: p. 72).

The conquistadors captured Tlaxcala and killed thousands of people and burned thousands of houses. After reaching the city of Cholula in October, the Spaniards destroyed it by depopulating it by massacring the people. One official of Cortés noted that the conquistadors "were dripping with blood and walked over nothing but dead bodies" (quoted in Kiernan, 2007: p. 90). Furthermore, Cortés and his army continued the conquest of the areas that became Guatemala and Colombia. He sent Pedro de Alvarado, his lieutenant, in 1523 with 120 cavalry, 300 infantry, and four artillery pieces to repeat the butchery of the indigenous in Mexico (Kiernan, 2007: p. 93) by using similar mechanisms of terrorism and mass killings. The colonial terrorists needed human trophies to terrorize the surviving population; they also used these trophies to demonstrate their achievements and convince the colonial governors that they accomplished their missions. Using their knives and "approaching the victims and pulling up their heads by the hair, they swiftly removed tender cartilage from the skulls of all the dead. After filling their sacks with the lightweight, blood harvest, the attackers returned to camp and prepared for another campaign" (Blackhawk, 2006: p. 16). The barbarism and cruelty of these terrorists were also demonstrated by their use of strings of dried ears in their homes (Blackhawk, 2006: p. 19). The Spaniards totally controlled the city of Tenochtitlan and Ixtapalapa in 1521; they destroyed Ixtapalapa by indiscriminately killing its people and reducing it to "human wreckage" (cited in Kiernan, 2007: p. 91). As Ben Kiernan (2007: p. 88) notes, "The contemporary population of what is now Mexico has been estimated at 12 million. After Cortés's conquistadors took over Anahuac in 1519-1521, that population fell by 85 percent, to as low as 1 million by 1600 , in what historians call 'one of history's greatest holocaust'."

Similarly, as Shirley A. Hollis (2005: p. 116) notes, the De
Soto expedition resulted in "demographic shifts throughout the Southeast [of North America] [and] brought about a significant social changes. Within two centuries of first contact, almost the entire indigenous population of the Southeast had been exterminated". It was not only the Spaniards that committed horrendous crimes in South and Central America. The colonial Portuguese also engaged in colonial terrorism in the area that is called Brazil today. With increased competition from Spain, France, and England to colonize Brazil, after thirty years of Cabral's expedition, Joăo III, the king of Portugal, granted to Martin Afonso de Sousa the right to establish the first official colony in Brazil at Saŏ Vicente. Then within short time the Portuguese monarch announced his plan to colonize all Brazil "already inhabited by hundreds of Indian groups" (Metcalf 2005: p. 77). The Portuguese settlers established alliances with indigenous American groups such as the Tupinikin through marriage strategies as headmen "adopted" outsiders as sonin-laws. These alliances gradually assisted the expansion of Portuguese colonization, and "Săo Vicente had six hundred colonialists, three thousand slaves, and six sugar mills [in 1548]. These slaves were Indians from traditional enemies of the Tupinikin" (Metcalf, 2005: p. 79). Since the private colonization initiative was not successful, the Portuguese king sent his governor to build the capital city in Brazil and to expand Christianity (Metalf, 2005: p. 83). The Portuguese promoted Christianity and racial slavery simultaneously.

Racial "slavery [was] firmly rooted in Brazil, where it would be the foundation of Brazil's economic development for nearly four hundred years" (Metcalf, 2005: p. 157). The Portuguese colonialists enslaved the Tupi, Guarani, Gê, and Arawak peoples; these "slaves cleared the first fields and planted them with sugarcane, [and...] built the first mills and produced the first sugar harvest. [Enslaved Africans] joined Indians on the sugar plantations in the first half of the sixteenth century, and the numbers increased rapidly after 1550" (Metcalf, 2005: p. 158). "Unlike Spanish America, where epidemics accompanied colonization, the first epidemics that likely occurred in Brazil before 1550 did not destroy the political or social structure of independent indigenous groups.... But between 1550 and 1580, Brazil began to follow a pattern similar to that seen in the Spanish Caribbean in the thirty years after 1492: significant outbreaks of disease coincided with the ratcheting up of the tempo of colonization" Metcalf (2005: p. 120). The processes of colonization, incorporation, and terrorism gradually moved from South and Central America to North America. "What Columbus did to the Arawaks [and the Caribs] of the Bahamas, Cortés did to the Aztecs of Mexico, Pizzarro to the Incas of Peru," Howard Zinn (2003: p. 11) writes, "and the English settlers of Virginia and Massachusetts to the Powhatans and the Pequotes". The European colonial settlers also began to have impacts on the culture and lifestyle of the North American Southwest by establishing trading posts and missions that further spread European diseases and "served as centers of contagion as well as centers of commerce" (Carlson, 2002: p. 426). Colonial and commercial activities also expanded to the Northwest with the second phase of fur trade in the 1820 s with similar results. From the beginning, the incorporation of the Americas into the European-dominated capitalist world system involved many webs of activities that included various forms of violence. "While nearly all colonial systems conducted forms of genocide, extending over a five hundred years period well into the nineteenth century," Thomas Hall and James V. Fenelon (2004, p. 
175) write, "most did not develop treaty based legal systems, but many in Central and South America incorporated American Indian peoples into systems of racial subordination, segregation and partial assimilation as minority groups" to continue subjugation and exploitation.

European states and their agents used colonial terrorism in committing genocide and in reorganizing peoples on a racial criterion; "these processes coincided with the spread of European diseases, which tore apart the social fabric, especially the system of marriage alliances" (Hall, 1993: p. 243). The spread of European diseases was extended for many centuries; contact was "temporally extended process, rather than a single instant or event that ruptured the otherwise pristine Garden of Eden into which the Europeans at first believed they had stumbled" (Whitehead, 1993: p. 288). Sometimes indigenous Americans were affected by diseases without encounters of any person from the European and African continents; since the spread of epidemics was not uniform the transmission rates were "affected by diet, physical settings, social practices and active native responses to epidemics" (Whitehead, 1993: p. 289). Some colonial forces intentionally used smallpox as a warfare to eradicate some indigenous Americans (Fenn, 2000). Exploring the several results of incorporation into the European-dominated capitalist world system, Christopher Chase-Dunn and Thomas D. Hall (1997: p. 59) note that some indigenous peoples were "eliminated, either by annihilation or assimilation into the absorbing group;" they also assert that "not much attention has been given to the incorporation of stateless worldsystems." Great Britain and France used similar political practices in establishing their colonies. The English did not successfully establish a colony until 1607 in North America. The Virginia Company under the leadership of Captain John Smith established this first settlement in 1607 in Jamestown, Virginia. After settling in Jamestown, the English settlers expanded their settlements that led to the opposition of the Powhatan people.

As this Virginia settlement grew and its population increased from 1300 in 1625 to 8000 in 1640, the settlers' policy "did not seek the Powhatans' total extermination, but it required their full subjugation, and eventual slavery for survivors" (Kiernan, 2007: p. 223). However, gradually the Powhatans were annihilated (Kiernan, 2007: p. 224). The English settlers continued to confiscate the lands of the indigenous peoples by using colonial terrorism. In 1621, the English pilgrims also settled at Plymouth in a section of the continent that later became New England and pursued policies of terrorism, extermination, and slavery on the Wampanoag, Narragansett, Pequot, and other indigenous peoples. To transfer the communal ownership of the lands of these peoples, the Puritans "developed a tactic of warfare used by Cortés...: deliberate attacks on noncombatants for the purpose of terrorizing the enemy" (Zinn, 2003: p. 14). John Winthrop, the governor of the Massachusetts Bay Colony, "created the excuse to take Indian land by declaring the area legally a 'vacuum'. The Indians, he said, had not 'subdued' the land, and therefore had only a 'natural right' to it, but no a 'civil right'. A 'natural right' did not have legal standing" (Zinn, 2003: pp. 14-15). Winthrop justified the establishment of private property through violence and expropriation. The Puritans asserted that the heathens who resisted the power of Europeans, God's children, should be condemned and lose their lands violently. As the Spaniards did, the British settlers engaged in terrorism and genocide in the process of transforming the communal ownership of the land of indigenous American peo- ples to the private property of the European settlers (Zinn, 2003: p. 16). In the seventeenth century, the Spaniards, English, French, Russians, and the Dutch simultaneously began to establish their permanent colonies in the area north of Mexico.

As the English settled at Jamestown in 1607, the French founded Quebec in 1608. The Russians also established furgathering posts on the Alaska Peninsula and exterminated the Aleut people. They "treated them with unspeakable cruelty; they raped the women and held them as hostages until the men ransomed them with furs; they destroyed settlements and murdered people from sheer barbarity. It is estimated that the population when they came was 25,000; a count made in 1885 showed 3892" (Debo, 1995: p. 83). After thirteen English colonies emerged as the United States after the American Revolution of 1776, the colonial settlers wanted to continue to expropriate the lands of indigenous Americans under different ideological pretexts. The United States began to expand to the Pacific west coast through terrorizing indigenous American peoples and expropriating their homelands. White Americans rationalized that it was God's will to control from the Atlantic Sea to the Pacific Sea and later across the continent and beyond. The United States intensified terrorism on indigenous peoples within its geo-political territories and in its neighbors and opened up western frontiers later in Texas, California, and the Great Plains to confiscate lands and other resources. American apartheid democracy under the leadership of George Washington, John Adams, Benjamin Franklin, Thomas Jefferson and others promoted colonial terrorism, war, expansion, and genocidal massacres on indigenous Americans. Soldiers, vigilante groups, and other settlers burned villages and towns, destroyed cornfields, massacred women, old men, and children, and scalped their heads for trophy.

In 1779, George Washington declared war on the six nations of the Iroquois northwest and ordered "to ruin their crops now in the ground and prevent them planting. That fall, General John Sullivan burned down 40 Iroquois towns and destroyed 160,000 bushels of corn. [American forces attacked one town and] 'put to death all the women and children, excepting some of the young women, whom they carried away for the use of their soldiers and were afterwards put to death in a more shameful manner"' (Kiernan, 2007: p. 325). After becoming President in 1801, Thomas Jefferson continued and intensified terrorism and war on indigenous Americans; he dispatched his general, George Rogers Clark and the US Army to attack, terrorize, and destroy the Cherokee, Shawness, Peankeshaw, Ouabash, Kickapoes, Mingoes, Munsies, Windots, and Chickasaws to remove or exterminate them (Kiernan, 2007: pp. 319325). He wrote a letter to John Page describing that "even friendly Indians as 'a useless, expensive, ungovernable ally", (Kiernan, 2007: p. 320). When he was the governor of Virginia, Jefferson also ordered attack on Cherokees and the forces of Arthur Campbell "destroyed over 1000 houses of the over hill Cherokees in $1780 \ldots$ The next year, John Sevier 'burned fifteen Middle Cherokee towns'. In 1782, Sevier's son took part in another campaign against Lower Cherokees, reporting 'We destroyed their towns, stock, corn, [and] everything they had"' (Kiernan, 2007: p. 325).

After purchasing Louisiana from France in 1803, Jefferson promoted the policy of voluntarily or removing forcefully indigenous peoples from the territory. In the letter he wrote to the German scholar Alexander von Humboldt in 1812, Jefferson testified the commitment of his policy to destroy indigenous 
Americans: "The confirmed brutalization, if not extermination of this race in our America is therefore to form an added chapter in the English history of the same colored man in Asia, and of the brethren of their own color in Ireland and wherever else Anglo-mercantile cupidity can find a two-penny interest in deluging the earth with blood" (Jefferson, 1813: pp. 792-793). Andrew Jackson also continued the process of terrorizing indigenous Americans after he was elected president in 1828; the plundering of the lands of the indigenous peoples was intensified through terrorism and racial/ethnic cleansing in states like Mississippi, Georgia, and Alabama. Jackson informed the indigenous peoples that since the federal government did not have power to help them, they should move to a new territory by abandoning their homelands. Supporting the forced removal of the indigenous Americans and the dispossession of their homelands, Jackson, in the State of the Union Address, said: "What good man would prefer a country covered with forests and ranged by a few thousand savages to our extensive Republic, studded with cities, towns, and prosperous farms, embellished with all the improvements which art can devise or Industry execute, occupied by more than 12,000,000 happy people, and filled with all the blessing of liberty, civilization, and religion?"

In the same speech, he professed the inevitability of the extinction of indigenous peoples to make room for the civilized people (Perdue \& Green, 2005: p. 127). One of the shocking examples of colonial terrorism and racial cleansing through forced removal was practiced on the Cherokee nation. "With the dispossession of the Cherokee Nation via the Trail of Tears," Amy H. Sturgis (2007: p. 65) notes, "the previous relocations of the Choctaw, Creek, and Chickasaw Nations, and the defeat and ejection of the Seminole Nation, new US policy toward Native America were established." The United States expropriated the lands of indigenous American peoples and created for them what was known as "an Indian Territory." In addition to forced relocation, the United States destroyed the institutions of indigenous Americans. The US government in Mississippi abolished the government of Choctaws in 1830 and forced them to move to Oklahoma between 1830 and 1833 . This resulted in the deaths of many of them due to the hardships imposed on them. Similarly, in Alabama the US government through various forms repression including terrorism forced the Creeks to surrender all their lands by breaking their resistance. In 1836, the Creek "men were placed in irons and their wailing women and children - a total of 2495 peoplewere transported to Oklahoma and, literally naked, without weapons or cooking utensils, were dumped there to live or die" (Debo, 1995: p. 119).

In the next year, 543 of them were hunted by the military and dragged into to the new place. Those who remained in Alabama "were hanged for participating in the 'uprising' and other were reduced to slavery;" overall, they had lost 45 percent of the population (Debo, 1995: pp. 119-120). Before their forced removal the Cherokee people had suffered in the hands of competing European colonial powers. These competing nations wanted to control different parts of North America and embroiled the Cherokees in their wars in the nineteenth century. By siding with the French or the British depending on a given circumstance, the Cherokee people paid dearly in many fronts. In the summer of 1776, the colonies of Georgia, South Carolina, North Carolina, and Virginia attacked and terrorized the Cherokee nation: "Men and women, and children fled to the forests as the invading army destroyed houses, fields, and granaries. At one town alone in upcountry South Carolina, the soldiers destroyed six thousand bushels of corn. The destruction so late in the year left no store for the winter and no time to replant. The soldiers killed most Cherokee captives on the spot, and many collected the seventy-five-pound bounty... for the scalps of Cherokee warriors" (Perdue \& Green, 2005: p. 7). The second tragedy came to the Cherokee people with the Indian Removal Act of 1838, which led to their relocation at gunpoint in Oklahoma. They arrived there without any children and with very few elders since they perished on the way through hardship and disease.

The settlers divided the leadership of this nation and introduced to them a civil war. The Cherokees suffered immensely in the hands of the Georgia Guard between 1938-1839. This guard "was composed of ruffians, who terrorized the Cherokees - putting them in chains, tying them to trees and whipping them, throwing them into filthy jails" (Debo, 1995: p. 121). As Amy H. Sturgis (2007: p. 3) describes, "as an event on the stage of world history, the Trail of Tears supplies one example of the international, ongoing phenomenon of ethnic cleansing." Between four and eight thousand Cherokees died in stockades during the Trail of Tears (Perdue \& Green, 2005: pp. 167-168). Similarly, in resisting their removal, the Seminoles also suffered the most of all; the United States paid costly in lives and money in its war against the Seminoles nation. According to Debo (1995: pp. 126-127), "The removal of the five great Southern [ethnonations] and its continuing aftermath were parallel in the North by events less spectacular but no less relentless. A few [ethnonations] escaped. Elaborate plans were made to remove the Iroquois, first to Arkansas, then to Wisconsin, finally to Kansas." Continuing pushing the indigenous peoples to the west, the US occupied California, Texas, and Oregon between 1845 and 1848 .

After occupying California in 1845, US regular forces, local militia, and settlers began to exterminate indigenous peoples through enslavement and direct killings (Kiernan, 2007: pp. 351-354). Genocidal massacres also took place on the Great Plains. Texas declared its independence from Mexico in 1836, and its government, militia, and settlers exterminated almost 20,000 of indigenous Americas (Kiernan, 2007: pp. 334-349). Texas expanded its territory by destroying indigenous communities. With the U.S. annexation of Texas in 1846, the extermination of indigenous peoples continued. The killers of the indigenous peoples also removed the remaining indigenous peoples from Missouri, Kansas, Arkansas, Iowa, Nebraska, and Texas. Finally the same policy was applied to the Apaches of the Southwest. In 1871 the US government developed an Apache policy, and the Congress appropriated seventy thousand dollars "to collect the Apache Indians of Arizona and New Mexico upon reservations" (Debo, 1995: p. 270). The Navajo, the Nez Perce, and the Sioux peoples were removed from their respective homelands in the same way. "From such policies came the reservation system, the practice of assigning native peoples to specified federal lands, and the trust system," Sturgis (2007: p. 65) notes, "the practice of the U.S. government holding funds owed to native nations on their behalf, much in the same way as guardians would hold property on behalf of their wards." After almost all surviving indigenous Americans were collected into reservation camps and separated from the white people, racial cleansing and genocide were almost completed. In order to further dispossess the indigenous peoples by break- 
ing up reservations, the US government passed the Dawes law of February 8, 1887. Privatizing and dividing reservation lands to each head of a family (160 acres for each family) resulted in selling and transferring lands to white settlers. France and Great Britain competed for dominance in North America.

The French allied with some indigenous groups and fortified the Ohio Valley region to prevent the British from settling further west. But in 1759 and 1760, the British conquered Quebec and Montreal respectively. In 1763, by the Peace of Paris, the British took control of French Canada and Spanish Florida and removed the French presence in North America. When the French and other Europeans started to explore and colonize Canada, there were more than 50 ethno-nations, known as Canadian First Nations, by some scholars, occupying their respective homelands. As other Europeans did, the French and English used them as allies during the battles of the eighteenth and nineteenth centuries. In addition to various forms of violence, the colonialists used diseases to destroy the indigenous Americans. In fact, in 1763, British military officials spread smallpox among indigenous Americans through distributing blankets and handkerchiefs infected with variola (Fenn, 2000; Kociumbas, 2004: p. 80). "Diseases transmitted to peoples lacking immunity by invading peoples with considerable immunity. Smallpox, measles, influenza, typhus, bubonic plague, and other infectious diseases endemic in Europe played a decisive role in European conquests, by decimating many people on other continents" (Diamond, 1997: p. 76). Unfortunately, the indigenous ethno-nations also engaged in unjustified wars, terrorism, and self-destruction without realizing the far-reaching consequences of their activities. Out of about 2000 ethno-nations, about 250 lived in North America, some 350 in Mexico and Central America, and about 1450 in South America (Josephy, 1991). They had separate and mutually unintelligible languages. During the arrival of Columbus, according to the estimation of demographers, there were about 75 million indigenous Americans in the three continents (Josephy, 1991: p. 6).

Some demographers estimated that "the first hundred years of European presence in America brought about the demise of ninety-five percent of the Native population, while others suggest that a death rate of seventy-five percent may be accurate" (Perdue, 2005: p. 18). Similarly, Howard Zinn (2003: p. 16) argues, "The Indian population of 10 million that lived north of Mexico when Columbus came would ultimately be reduced to less than a million. Huge numbers of Indians would die from diseases introduced by the White" and by the wars of the rival European powers introduced by using the indigenous peoples as their pawns. "History still teaches falsely that pre-Columbus America was a wilderness, a virgin land, virtually untenanted, unknown, and unused," Alvin M. Josephy (1991: p. 6) writes, "waiting for the white explorers and pioneers, with their superior brains, brawn, and courage, to conquer and 'develop' it." The process of hero-making and the efforts of hiding the crimes committed against humanity in the Americas in the names of God, commerce, religion, culture, progress, and civilization by the European colonizers and their descendants have limited our understanding of the humanity, cultures, and the true history of indigenous American peoples. According to Noam Chomsky (1993: p. 5), "The conquest of the New World set off two vast demographic catastrophes, unparalleled in history: the virtual destruction of the indigenous population of the Western hemisphere, and the devastation of Africa as the slave trade rapidly expanded to serve the needs of the conquerors, and the conti- nent itself was subjugated. Much of Asia too suffered 'dreadful misfortunes"."

\section{The Gross Human Rights Violations of Indigenous Africans}

For almost five centuries, European empire builders, namely Portugal, Holland, France, England, Belgium, Germany, Italy, and Spain employed different strategies and tactics in Africa to make money through the ownership of human beings, exploration, evangelization, colonization, commercialization, terrorism, banditry, robbery, and theft. The processes of merchandizing some young Africans, dominating and controlling trade, destroying African institutions, cultures and religions, imposing Christianity, destroying African leadership and sovereignties through establishing colonial governments, dispossessing lands and other economic resources, and transforming Africans into coerced laborers involved war and terrorism. "Everywhere the conquests of Africa brought similar paradoxes of public disaster and private profit in their train" (Lonsdale, 1985: p. 722). When various African peoples intensified their respective resistance to racial slavery, colonial expansion, domination, and exploitation and later engaged in national liberation struggles, some of these empire builders increased their levels of terrorism to prevent the reemergence of African sovereignties and to continue their theft and robbery of African resources. Jean Ganiage (1985: p. 157) describes that European policy makers planned and acted "to crush African resistance by a ruthlessly systematic exploitation of the technological gap between European and African weaponry and military organization".

Indigenous Africans were exposed to two waves of terror: The first wave started in the late fifteenth century with merchandising of some young Africans at gunpoint and colonizing some limited coastal islands or territories (about 10 percent of Africa). The second wave emerged in the first half of the nineteenth century and consolidated with the partition and colonization of the whole continent in the same century. European countries and others that involved in Africa try to forget the deaths and sufferings caused by racial slavery, the blood spilled, mass murdered, the severed hands and heads, and the shattered families and other crimes committed in Africa to extract wealth and capital. As Adam Hochschild (1998: p. 295) puts, "Forgetting one's participation in mass murder is not something passive; it is an active deed. In looking at the memories recorded by the early white conquistadors in Africa, we can sometimes catch the act of forgetting at the very moment it happens." The practices of attacking, raiding, capturing, and owning human beings, as well as the dispossessing of the coastal lands of African peoples involved the first wave of colonial terrorism. The slavers and colonizers also used various forms of violence to force people to forsake their individual and group sovereignties in order to use them as commodities and to exploit their labor and economic resources.

Enslaving some young Africans involved warfare, trickery, banditry, kidnapping, burning villages, raping, torturing, dividing and destroying communities, facilitating civil war, and destroying existing leadership and institutions and cultures. Between 13 and 15 million young Africans were merchandized as commodities by European slave traders and their African collaborators and transported to the Americas. There were also Africans who were enslaved by Arabs and their African collaborators and exported to Asia. Furthermore, millions of 
young Africans were also merchandized and worked on European plantations, farms, and mining in Africa; some of them worked as domestic workers and porters, too. The development of mercantilism in Western Europe in the late fifteenth century enabled some European countries to have technological knowledge to build ships and cannons and to navigate seaways and gradually establish control overall the world's sea ways such as the North Sea, the Atlantic, Pacific and Indian oceans, and the Mediterranean Sea. Consequently, some European powers started to own sea-going vessels and cannons and to finance the exploration of the unknown continents. Portugal started to stage racial slavery and colonial expansion to overcome the problem of food deficit and to seek overseas' wealth; the technology of ship building and the availability of guns enabled the Portuguese first to colonize the islands of Azores and Madeira to cultivate wheat by using the labor of European migrants driven by hunger and captured slaves raided from the African coast (Birmingham, 1999: p. 2).

The Portuguese colonialists also captured and settled the Canary Islands, the offshore islands of Morocco, and occupied the Morocco fortress of Ceuta in the fifteenth century. After controlling the Atlantic Coast of Morocco, the Portuguese colonized some parts of African coast, established sugar plantations on the islands, and built trade factories on the beaches. Portuguese ambitions in Africa were diffuse during the sixteenth and seventeenth centuries: "One was to secure manpower to exploit in Brazil and the island colonies, but the Portuguese state and Portuguese merchants were equally interested in the spice trade, in precious metals, particularly gold, and in forging strategic alliance aimed against Mameluk Egypt and then the Ottoman Empire" (Freund, 1984: p. 40). To satisfy the needs of labor and commerce and to collect information on Africa, raiding, capturing, and owing Africans became an important enterprise for the Portuguese (Davidson, 1961: pp. 33$34)$. Realizing the profitability of the slave trade, those merchants who were not convinced about the profitability of slavery changed their mind: "The outcome of their talking was financial support for a large expedition of six ships... and a small scale war on the western coast in which one hundred and sixty-five men, women, and children were taken captives 'besides those that perished and were killed"' (Davidson, 1961: p. 37). Slave merchants started to send expeditions to import more and more slaves to Europe and the Americas. The Portuguese through "a diplomatic mission of friendship and alliance" with the agreement of the leaders of the people built their first fort called Elmina ("the mine") on the Coast of Gold Coast (now Ghana) in 1481 to get access to African slaves and gold (Humbaraci \& Muchink, 1974: p. 85).

The slave labor helped Portugal to experiment her colonial practices on the Atlantic and the Cape Verde islands, which became known for textile industry. Furthermore, the Portuguese merchants developed a colonial plantation economy on the Atlantic Coast of Africa and Brazil (Birmingham, 1999: p. 5). Later, other European powers learned from the experiment. Portugal also extended its imperialist and trade influence on the East African coast in the sixteenth century and involved in what is today Kenya, Tanzania, and Abyssinia (now Ethiopia) as part of its broader Indian Ocean strategy (Freund, 1985: p. 41). It forced the Swahili coastal towns to submit or form alliance. Portuguese expeditions also engaged in sacking and plundering African cities. Although it was not successful, Portugal attempted to impose Catholicism on ruling houses and mobilize them against Muslim empire builders. The Portuguese established her sphere of influence in the Zambezi valley, Zimbabwe, and the Congo, too. They created permanent settlements in Angola and Mozambique. Gradually the Portuguese colonies included Angola, the islands of São Tomé and Príncipe, Guinea Bissau, Cape Verde Islands, and Mozambique. Portugal founded Luanda, the capital city of Angola, in 1575; it was the oldest European colonial settlement in the south of the equator. Although salt, iron, copper, ivory, and gold attracted the Portuguese to Africa, "slaves were always more important than [other commodities] in the mobile zones of frontier exploitation that were opened up by ocean navigation in the Atlantic" (Birmingham, 1999: p. 17).

After the Scramble for Africa, Portugal intensified its policies of effective control and pacification to prevent loses of its colonies to its rival imperial and internal resistance forces. Between 1870 and 1905, the Portuguese effectively colonized the interior of Angola and Mozambique through series of wars and terrorism (Smith, 1985: pp. 493-520). According to Bruce Vandervort (1998: p. 146), "The Portuguese imperial renaissance of the $1890 \mathrm{~s}$, spurred on by national indignation at the country's humiliation at the hands of her imperial rivals, meant war for the peoples who inhabited the African lands over which Portugal claimed sovereignty. In Angola, beginning in the 1880 s, Portuguese columns made increasingly vigorous efforts to break out of the coastal regions and on to the central plateau, to penetrate the northern rain forests and to bring the arid lands of the far south under effective control. In Guinea-Bissau... Portuguese military pressure on the interior increased... Mozambique, however, was the major arena of Portuguese colonial warfare." There were various peoples and independent kingdoms that refused to recognize the colonial power of Portugal and resisted to pay taxes and to work on colonial projects and plantations. The Portuguese army and African mercenaries used warfare and terrorism to break the will of these Africans (Vandervort, 1998: p. 148). They engaged in what they called the wars of pacification, which caused thousands of deaths and exiles. With increased resistance in Angola and Mozambique, the Portuguese colonial forces terrorized the indigenous peoples, destroyed cultures, institutions, and communities, denied wells during drought, and killed or exiled leaders (Herbert, 2003: pp. 29-38).

After the mid-1950s different nationalist groups that later formed nationalist movements emerged and demanded national independence. To respond to these conditions, the colonial government and its army intensified terrorism to prevent them from fighting for their rights. "No child grew up in Angola without risking a daily encounter with violence," David Birmingham (1999: pp. 133-134) writes, "police violence, gang violence, domestic violence, conscripted violence, exiled violence, the violence of permanent fear permeating a whole society and a whole generation." As soon as the MPLA (Movimento Popular de Libertação de Angola) started the Angolan liberation struggle in September 1962, thousands of refugees moved to neighboring countries (Humbaraci \& Muchnik, 1974: p. 123). The condition in Mozambique was not different. The uprisings of the sugar-cane plantation workers and dock strike in 1963 met with bloody reprisals, arrests and deaths (Humbaraci \& Muchnik, 1974: pp. 146-147). With the intensification of the national struggle under the leadership of FRELIMO (the Mozambican National Resistance), most nationalists were terrorized and brutalized by the Portuguese forces. Furthermore, 
Western European and American financial aid contributed to the suppression of these Africans. As Birmingham (1999: p. 234) explains, "The more the West [supported] the forces of minority white domination in Africa, the more Angola, Guinea Bissau and Mozambique [would] be different from those countries who had their independences granted-sometimes virtually on a silver platters."

Inter-European competition for slaves to man their mines and plantations of the Americas intensified racial slavery in Africa. England, France, Holland, and Spain also participated in the Atlantic slave trade for more than three centuries. These European powers with their African collaborators terrorized and dehumanized some young Africans that they were enslaving. "Where warfare and violence stimulated the initial capture," Joseph C. Miller (2002: p. 45) writes, "the victims would have begun their odysseys in exhausted, shaken, and perhaps wounded physical condition." Since raiding, capturing, merchandising human beings, and transporting them involved several lethal dangers, a great portion of the enslaved Africans perished. As Henry W. Nevinson (1906: p. 113) expounds, "The path is strewn with dead men's [and women's] bones. You see the white thighbones lying in front of your feet, and at one side, among the undergrowth, you find the skull. These are the skeletons of slaves who have been unable to keep up with the march, and so were murdered or left to die." Those enslaved Africans who survived the danger of death were dehumanized and treated less than animals: "The great majority of the slaves went directly to the slave pens... These barracoons - a word also applied to farmyards for keeping animals-were usually barren enclosures... Large numbers of slaves accumulated within these pens, living for days and weeks surrounded by walls too high for a person to scale, squatting helplessly, naked, on the dirt and entirely exposed to the skies except for a few adjoining cells where they could be locked at night. They lived in a 'wormy morass'... and slept in their own excrement, without even a bonfire for warmth" (Mills, 2002: p. 49).

"All slaves trembled in terror at meeting the white cannibals of the cities, the first Europeans whom many of the slaves would have seen. They feared the whites' intention of converting African brains' into cheese or rendering the fat of African bodies into cooking oil, as well as burning their bones into gunpowder" (Miller, 2002: p. 49). The European powers used various forms of violence to acquire free or cheap labor and to invade and take over African lands and others resources while claiming that they were promoting Christianity, civilization, and modernity. The second phase of colonial terrorism was the continuation of the first one. Between 1830 and 1845 in Algeria, the French army engaged in terrorism, killing men, women, and children, and annihilating some clan families, beheading their leaders, setting fires, "smoking ... men, women and children to death," and throwing hundreds of corpses in caves (Kiernan, 2007: p. 365). The French military leaders in Algeria "ordered summary executions on the slightest suspicion, [and] showed "unnecessary cruelty"' (Kiernan, 1982: p. 73). Within the first three decades, the French military massacred between 500,000 and 1 million from approximately 3 million Algerian people (Kiernan, 2007: pp. 364-365). According to Kiernan (2007: p. 374), "By 1875, the French conquest was complete. The war had killed approximately 825,000 indigenous Algerians since 1830. A long shadow of genocidal hatred persisted, provoking a French author to protest in 1882 that in Algeria, 'we hear it repeated every day that we must expel the native and if neces- sary destroy them'."

The French burned the city of Constantine; 20,000 French troops "bombarded and attacked the town of 30,000, leaving corpses of the inhabitants strewn 'everywhere on the ground.' 'The threshold, the courtyard, the stairs, the apartments, all these places were covered with bodies so close together that it was difficult to take a step without treading on them. And what to say of this trail of bodies on the torturous contour of the precipice where the unfortunate women had tumbled with their children on being seized with fright at our entry into the town"' (Kiernan, 2007: pp. 368-369). All these crimes against humanity were committed to cow the Algerian population. Some lands of Algerians were expropriated and given to the French settlers. The French settlers reached 4000 families in 1882, and the colonial government established 197 settlements by granting lands freely totaling 347,000 hectares (Ganiage, 1985: p. 163). The more the French increased terrorism and repression, the more Algerians resisted colonial domination. During the night of November 1, 1954, a handful of armed nationalists confronted French soldiers. Considering this event as a dangerous condition and labeling the repressive measures of the colonial government as "the struggle against terrorism", the colonial government expanded the legal powers of the army and the police (Branche, 2004: p. 135). Consequently, the French army targeted both combatants and civilians and "two acts of violence grew exponentially: summary executions and internment in camps" (Branche, 2004: p. 138).

"The execution of hostages owed its genesis to colonial law, which assigned collective responsibility in the case of certain infractions, and authorized collective punishments, including forced labor. This principle was enforced in the spring of 1955: if an attack took place, the nearest village was considered collectively responsible. The reprisals that ensued might include executing hostages" (Banche, 2004: p. 139). Tortures, beatings, and rapes were also used as forms of colonial terrorism: "Torture sessions began with the systematic stripping of the victim. One method of torture was rarely used alone. It was more often combined with one of five separate tactics: beatings, hanging by the feet or hands, water torture, torture by electric shock, and rape" (Branche, 2004: p. 140). Rape was a theatre of violence in Algeria; gang rapes were often common. Rape as an act of terrorism was intended to impose psychological destruction on Algerian society. As Raphaël Branche (2004: p. 141) states, "This particular act of violence struck a well-aimed blow at one of Algerian society's foundations: the virginity or 'purity' of women. It also attacked the manhood of Algerian men, which relied upon their ability to defend their women." As the Algerian national struggle was intensified, the French colonial government increased colonial terrorism although it failed to crush the will of the Algerian people. Finally, Algeria achieved its political independence in 1962. Other European countries continued similar policies and practices. The first Dutch settlers arrived in the Cape peninsula in 1652. Dutch East India Company occupied the Cape peninsula under the leadership of Jan van Riebeeck (Thompson, 2001: p. 32). In 1662, the Cape of Good Hope emerged as a complex and racially stratified society.

Although the Dutch settlers initially established fairly cordial relationship with the Khoikhoi and acquired sheep and cattle in exchange of European goods, they gradually started to use violence to dispossess their lands and forcing them into slavery. The settlers began to have upper hand on the Khoikhoi and 
other indigenous peoples because of the superiority of their organization, weaponry, and the divisions among the indigenous peoples. The Dutch settlements expanded from generation to generation. According to Leonard Thompson (2001: p. 38), "Gaining confidence from their defeat of the peninsula people, the settlers became increasingly brutal. They branded, thrashed, and chained Khoikhoi." The settlers first destroyed the sovereignty of the Khoikhoi by expropriating their economic resources and by destroying their leadership, institutions, and culture and reducing them to the status of slaves or coerced workers (Freund, 1984: pp. 55-56). The Pastoralist Boers "relied on Hottentots [Khoikhois] and, later, Bantu serfs, who cost nothing but little food, and whose destitution forced them into the service of the Boers after the latter had deprived them their land" (Den Berghe, 1970: p. 23). Initially the Dutch East India Company expropriated their economic resources such as land and "livestock - their most valued possessions: the records of the company show that between 1662 and 1713 it received 14,363 cattle and 32,808 sheep from the Khoikhoi. Their fragile political system had collapsed, and the chiefs had become pathetic clients of the company. In the 1680 s, individuals and families had begun to detach themselves from their society and serve burghers as shepherds and cattle-herders" (Thompson, 2001: p. 38).

The European diseases such as smallpox finally annihilated the Khoikhoi pastoral society. The settlers also invaded, terrorized, destroyed, and used the remaining population of San, hunter-gathers society, as slaves or coerced workers. Then they continued to attack, colonize, and destroy African farming communities. Although the Bantu-speaking Africans such as Xhosa and Zulu who were mixed farmers seriously resisted the incursion of Europeans to their homelands, they were also defeated and dominated after many centuries. Because of the essence of their social formations, the occupationally differentiated Africans, namely Koikhois, San, and Bantu speaking Africans (such as the Zulu, Ndebele, and Sotho) had varied experiences with their European enemies. Relatively speaking, it was more difficult to attack, colonize, and destroy the African farming communities than the pastoral and hunting-gathering communities. The Dutch colony was expanded on different directions without any competition until 1795 (Theal, 1969: pp. 96-111), when England captured the Cape from the Dutch. The Boers viewed the San as vermin; their commandos killed 503 and captured 239 in 1774, and killed 2503 and took as prisoners 669 between 1786 and 1795 (De Berghe, 1970: p. 24). After 1795, both the Dutch and English colonial settlers continued the policy of terrorizing and annihilating the indigenous peoples of South Africa. Those indigenous Africans who lived in the eastern part of southern Africa were terrorized and colonized during the early nineteenth century: "In 1811 and 1812, in a campaign that set the precedent for the piecemeal conquest of all the black farming people of Southern Africa, British regular troops, assisted by colonial commandos and Khoikhoi units, ruthlessly expelled the Xhosa inhabitants from the land through to the Fish River, burning crops and villages and making off with thousands of head of cattle" (Thompson, 2001: pp. 54-55).

After occupying the Cape peninsula, like the Dutch, the British settlers started to terrorize and colonize the frontier political and farming communities. John Cradock, the British military governor of the Cape of Good Hope outlined his plan to annihilate the leadership and communities such as Xhosa; he explained that "the expediency of destroying the Kaffir [Bantu speakers] Kraals, laying waste their gardens and fields and in fact totally removing any object that could hold out their chiefs an inducement to revisit the regained territory" (quoted in Magubane, 1996: p. 45). He started the frontier war and terrorism of 1811-12. According to Bernard M. Magubane (1996: p. 45), this "was total war because it did away with the distinction between military and civil categories. It was total war because it affected all levels of individual and community life: political, economic, psycho-social, and military". After they were removed from their homelands, the surviving Xhosas became coerced workers for the British settlers. With the discovery of diamonds and gold in 1867 and 1884 respectively in Kimberly and Witwatersrand, the British colonial government intensified colonial terrorism. Those Africans who survived were disarmed and settled on reservations; they were forced to be coerced laborers in mining and farming industries. Despite the fact that the southern African kingdoms and societies initially established friendly commercial relationship with Europeans, the Europeans wanted to own African lands by violating the norms of society: "White farmers... claimed to own the land they had been permitted to use, whereas the idea that a person could have property rights in land did not exist in African culture" (Thompson, 2001: p. 71).

The Europeans settlers used the cleavage in African societies, firearms, and the Africans "lacked the equipment to capture fortified positions or laagers composed of circles of wagons, and when Africans resorted to guerrilla tactics the invaders forced them into submission by attacking their food supplies. Time after time, Afrikaner [Dutch settler] commandos and British regiment brought Africans to their knees by systematically destroying their homes, crops, and grain reserves, seizing their livestock, and turning their women and children into refugees" (Thompson, 2001: p. 72). Both the Dutch and the British contested to own African resources such as land, cattle, labor, and minerals. However, in 1870 "African kingdoms, Afrikaner republics and British colonies co-existed in a rough equilibrium of power, but pursuing widely differing social and economic goals" (Marks, 1985: p. 359). During the Scramble for South Africa between 1877 and 1895, South Africa emerged as a "white man's country" (Schreuder, 1980: pp. 4-9). According to D. M. Schreuder (1980: p. 9), "What mattered most of all was that the local balance of power had tilted permanently against the authority of the African political communities in favor of the Europeans; that the peculiar modern politicaleconomy of the region had been formed; and that the settlement patterns - particularly those of territorial segregation and the 'right to the land' - were ultimately decided." How did all these happen? Particularly it was not easy for the Dutch and English settlers to terrorize and dominate the Zulus; "for most people in Europe and America, recognition of the valor of African fighting men begins and ends with the Zulus" (Vadervort, 1998: p. 102).

Moving to the Zululand, the Afrikaners attacked the Zulus in December 1838. Despite the fact that the Zulus were well organized under their able king Dingaan, Shaka's successor, their invading enemies massacred them. According to Bruce Vadervort (1998: p. 109), "It was a rude shock for the Zulus, who fell by the thousands to Boer elephant guns on the banks of the Ncome River in Natal." Consequently, the Boers colonized Natal and declared it a republic; however, the British took Natal from Boer in 1846. The Boers left the republic and moved to the Boer republics in the Orange Free State and the Transvaal. 
Now the British had to face the Zulus. Although the Zulus challenged the British at many war fronts, they finally lost "the war because their traditional military strategy of head-on engagement in the long run could not prevail against the breech-loading rifle" (Vadervort, 1998: p. 111). The British also used the divide and conquer strategy to destroy the power of the Zulus. More than the war with British, the ensuing bloody civil war between Zulu factions destroyed the Zulu kingdom in the 1880s. With the Zulu rebellion of 1906, the British increased their violence; more than 3380 people were murdered or hanged, thousands imprisoned; hundreds of leaders were annihilated (Herbert, 2003: pp. 85-93). Although the Dutch and English colonialists defeated the Zulu and other African farming communities, expropriated their lands and livestock, and forced some of them into coerced labor, they could not disintegrate these communities because they were conditioned to the diseases brought from Europe, their numerical superiority to the settlers, "their economy was more complex, their social networks were far more resilient, and their political systems were far more durable" than the hunter-gatherers and pastoral communities (Thompson, 2001: p. 72).

Despite the fact that "the white settlers were few in number, their polities were frail, and their pockets of settlement were bordered by autonomous African polities", "the white impact intensified dramatically as a result of the discovery of the world's greatest deposits of diamonds, soon to be followed by gold, in the heart of southern Africa" (Thompson, 2001: p. 72). According to Leonard Thompson (2001: p. 109), "Great Britain, unchallenged by European rivals, dominated the external trade of the region. In spite of the ambition of their creators, the Afrikaner states were inexorably part of the informal British empire." Both the British army and militia and Afrikaner commandos dominated Africans through colonial terrorism and transformed Southern Africa in the last decades of the nineteenth century. Finally, the British army defeated the Afrikaner republics between 1899 and 1902, and formed the Union of South Africa in 1910. At the end, all African groups were brought under white domination in Southern Africa for almost five centuries. The Dutch and English colonizers justified their colonial terrorism and the establishment of the racist political economy and structures in the discourses of racial superiority, Christianity, and European civilization. In these complex processes, the violent racist state and apartheid society were born in South Africa. Furthermore, the British forces colonized Lesotho in 1844, Botswana in 1896, and Swaziland in 1906.

Similarly, in 1890, the British expedition force consisting of 184 English and Afrikaners and 300 black mercenaries violently occupied Southern Rhodesia (now Zimbabwe) and Northern Rhodesia (now Zambia) in 1891 under the leadership of Cecil Rhodes and the company called the South Africa Company; these forces settled there and confiscated the lands and cattle of the Ndebele and Shona peoples (Turok \& Maxey, 1985: pp. 248-249). Overall, the process of terrorizing and colonizing Africans were intensified; these colonial projects exposed almost all of African peoples to European domination and their collaborators and forced them to lose their sovereignties and economic resources (Sanderson, 1985: pp. 96-158), facilitated the destruction of independent leadership and societies, and caused millions of deaths through various forms of violence and diseases. The European colonial powers used commerce, religion, and terrorism to acquire what they wanted from Africans. A few African leaders initially "misunderstood the objectives of the colonial enterprise" (Falola, 2002: p. 182) and signed the so-called treaties with the European powers; "African leaders signed documents to show that they surrendered their power and agreed to promote trade and accept other conditions. There is no evidence that many African chiefs understood the contents of the treaties" (Falola, 2002: p. 179). Of course, most African leaders and societies did not sign treaties with the European powers and resisted European colonialism to retain their sovereignties and protect their lands and other economic resources, institutions, and cultures. Some of those African leaders who signed treaties also resisted European colonialism after they realized the intentions of the European powers.

The Europeans had the power of technology, organizational capacity, and resources to build and use professional armies devoted to full-time war and terrorism; they had the ability to recruit large armies of African mercenaries who were ready to fight on their behalf in Africa and to provide information on Africa. According to Toyin Falola (2002: p. 183), "The Europeans relied on improved firearms. Africans used bows, arrows, and muzzle-loading guns (such as Dane guns), which had to be loaded slowly. The European armies in the area of the partition relied on breech-loaders, rifles that could fire at the rate of about ten rounds per minute. Whereas the European armies had adequate modern guns (the Maxim and Gatling), their African rivals lacked access to them." Using professional armies and modern guns, the Europeans intensified ruthless wars and terrorism on resisting African societies and forced them to accept European colonialism by the threat of violence. France colonized some African coastal areas in the seventeenth century and Algeria in the early nineteenth century. Although France formed the French West Africa in 1895, since the seventeenth century it controlled St. Louis, Rufisque, Gorée, and Dakar in Senegal, Grand Bassam and Assini in Côte d'Ivoire, and in a small coastal area in Dahomey (now Benin). The French Federation of West Africa consisted of Senegal, Côte d'Ivoire, Niger, Benin, French Sudan (now Mali), French Guinea, Mauritania, and Tog (after WW II). France also established its colony in East Africa; it colonized Obock, an important comercial center on the Red Sea in 1862.

In addition, it occupied the Ambado and Djibouti areas between 1885 and 1892; Djibouti became the capital of French Somaliland in 1896. France also occupied Tunisia in 1881 and part of Morocco in the late nineteenth century. After establishing their first foothold for about two hundred years at a trading post called St. Louis at the mouth of the Senegal River, "French traders had seen the Senegal as a highway into the interior of West Africa, to exotic place like Timbuktu, which they believed to be the source of a rich trade in ivory, gems and gold. But disease and powerful African opponents made expansion into the interior an extremely difficult process, and for a long time French commerce in West Africa was largely confined to the trade in human beings" (Vandervort, 1998: p. 70). The French merchants used St. Louis and the island of Gorée in the seventeenth and eighteenth centuries for slave trade and for sending slaves to the French sugar plantations in the West Indies. After the 1850s, France started to expand its colonial expansion into the interior of Senegal. It intensified the war of colonial expansion and terrorism between 1870 and 1905 (Person, 1985: pp. 208-256). The French army raided villages, burned homes, destroyed crops, and driven off herds. Despite the fact that the Tukolors who were related to the Fulani tried their best to resist French colonialism under the leadership of 
al-Hajji Umar, they were defeated because of the firepower and the greater mobility of the French army (Vandervolt, 1998: p. 79). Ahmadu Seku, the eldest son and chosen successor of al-Hajji Umar tried to prevent the destruction of the Tukolor Empire. However, in 1889, Segu, the capital city of Ahmadou was captured; then the conquest of fabled Timbuktu followed. Then France turned to fight against Samori Touré (1830-1900), one of the greatest leaders in West Africa.

His military genius and political acumen could not save his country from French colonialism, and he was captured in 1898 and died in 1990. France also colonized Wadai (now the Republic of Chad) between 1909 and 1912. Wadai was suffering from the destruction of slavery during the arrival of the French. The French installed their puppet chiefs such as Acyl and others, destroyed those leaders that opposed to French colonialism, and ruled Chad until the mid-1960s. In French West Africa, the Tuareg revolted in Southern Sahara from 1916 to 1917. In Niger, they were terrorized, killed, and ruthlessly repressed (Herbert 2003: 1201). Similarly, the pacification of the Ivory Coast involved war, terrorism, and the destruction of leadership and society. When in the homeland of Baoulé, guerrilla warfare continued between 1898 and 1900 the French increased terrorism and repression (Suret-Canale, 1964: p. 96). The French colonial government gave full power to its police to collect taxes from people who were resisting colonial rules: "tax... gathered at the cost of villages burnt down, chiefs and natives killed in large numbers, heads of chiefs put up on poles, the imposition of fines" (quoted in Suret-Canale, 1964: p. 99). In North Africa, France expanded its colonial occupation from Algeria to Tunisia in 1881 and Morocco in 1906 (Ganiage, 1985: pp. 159-207). The last Moroccan guerrilla fighters resisted French colonialism until 1934. The "pacification" of the fierce Berber fighters of Morocco by the French started between 1903 and 1904. In 1912, France established its protectorate on Morocco. In 1904 the French and Spanish colonial governments decided bilaterally that the northern coastal region would be regarded as a Spanish zone of influence, and the eastern Morocco would be under French influence.

Furthermore, France colonized Madagascar in 1896 through ruthlessly terrorizing various indigenous peoples in the island (Deschamps, 1985: pp. 521-538). During the turn of the twentieth century, France used five measures to eliminate the possibility of resistance. It completely disarmed the people, arrested and deported leaders, imposed payment of retroactive taxes and war fine, imposed coerced labor and annual tax payment, and destroyed camps and settlements in villages (Suret-Canale, 1964: pp. 100-102). Since the people revolted against these measures, the French forces used terrorism and systematic political repression (Coquery-Vidrovitch, 1985: pp. 298-315). The police toured the villages, attacked communities, and ravaged their crops to force them to pay taxes. As Adam Hochschild (1998: 280) expounds, "In France's equatorial African territories... the amount of rubber-bearing land was far less than what Leopold controlled, but the rape was just as brutal. Almost allexploitable land was divided among concession companies. Forced labor, hostages, slave chains, starving porters, burned villages, paramilitary companies 'sentries', and the chicotte [whipping] were the order of the day." In the French Congo to celebrate Bastille Day two white men "had exploded a stick of dynamite in a black prisoner's rectum" (Hochschild, 1998: pp. 280-281).

Social destruction and colonialism were expanding in Africa in all directions. When the Turko-Egyptian forces were weakened and abandoned garrison towns on the Somali coast, Harar, and eastern Oromia, "European imperialism became more active, and the three western powers already involved in the Horn of Africa strove to fill the vacuum. The British occupied the ports of Zeila and Berbera, the French made treaties with the sultans of Tadjoura and Gobaad for cession of their territory, and Italians asserted claims to the Assab area" (Thompson \& Adloff, 1968: p. 7). Italy occupied Libya in 1911 and Massawa in 1885. Britain's colonialism of Somaliland was not limited to the coast but extended to the hinterland later called British Somaliland. Somalia was partitioned among four countries, France taking the north, Britain the middle, Italy the south, and Abyssinia (Ethiopia) the west. "It was the British who came in for most of the rough work," V. G. Kiernan (1982: p. 81) notes, "having to take on the celebrated 'Mad Mullah', another of those enigmatic personalities - he was a gifted writer as well as partisan - who led... the old Islamic world against European intrusion, but were at the same time harbingers of something new, national unification." The resistance of Somalis to British colonialism under the leadership of Mohammed Ibn Abdullah Hassan who the British called the "Mad Mullah" brought terrorism and war on Somalis. The warrior Mullah attacked those who collaborated with the enemy, collected arms, organized men into military, and preached a holy war against the colonial occupying forces (Herbert, 2003: p. 57). The British sent several expeditionary forces against this "political and military leader of the highest caliber" and his followers, terrorized and killed thousands of people, burned villages, raped women, and looted resources" (Herbert, 2003: pp. 57-67).

The British also mobilized 5000 Abyssinian/Ethiopian soldiers against the Somalis. Their attack that started in 1901 against the Somali resistance forces ended in 1921, when the British and the Abyssinian armies defeated the followers of the Mullah. After colonizing Egypt in 1882, Britain occupied the areas now called Kenya 1896, Uganda, the island of Zanzibar, and Sudan in 1899. By declaring protectorate over present-day Kenya, Uganda, and island of Zanzibar, Britain established British East Africa. The indigenous peoples of these areas resisted British colonialism; when the colonial office intensified land expropriation, taxation, and recruitment of coerced labor, they attacked white officials, settlers, and traders (Herbert 2003: p. 78). To crush this resistance, the British started to raid and terrorize these peoples. One of the indigenous peoples that defied the Pax Britannica was the Nandi who lived in the hills northeast of Lake Victoria. The British colonial office established the Nandi Field Force in 1905 to terrorize, defeat and destroy the Nandi community. The force killed 1117 Nandis, looted 16,000 cattle, 36,000 sheep and goat, burned 5000 huts and grain stores, and forcefully moved the surviving population to reservations (Herbert, 2003: p. 80). In 1900 one official expressed that "the England of today, intoxicated with militarism, blinded by arrogance, indifferent to truth and justice" (quoted in Kiernan, 1982: p. 178). Like the Nandi, the Embu and Kikuyu peoples revolted in Kenya because their economic resources particularly their lands were given to white settlers. The Kikuyu formed the Land and Freedom Guerrilla Army that the British called Mau-Mau; in 1963, when Kenya achieved its independence 11,500 Kikuyu were murdered when only 32 white settlers were killed (Herbert, 2003: p. 85).

Similarly, refusing to pay taxes, providing labor and forced relocation, the Giriama rebelled in 1914 against British coloni- 
alism in Kenya: "The colonial administration had attempted to introduce taxes and to relocate people according to the requirements of the labor market, in order to boost economic conditions along the coast" (Herbert, 2003: p. 219). The British forces destroyed the fort of Kaya Fungo and raped women that sparked the fire of rebellion. At the end of the year, the Giriama were terrorized and cowed by the British expeditionary forces and 150 of them killed, 5000 of their huts burned, and 3000 of their goats confiscated (Herbert, 2003: p. 220). British colonialism was expanding to other parts of Africa. When Britain was sending its colonial army from Egypt to occupy Sudan, there was a politico-religious movement known as Mahdia that was struggling against Turko-Egyptian colonial domination in $\mathrm{Su}-$ dan. The religious leader who called himself the Mahdi led this movement. One of the Mahdi's best generals, Abu Anja, defeated the Anglo-Egyptian army of 8500 men at the battle Shaykan in November 1883 (Vandervort, 1998: p. 168). When Britain sent her famous general, Charles George Gordon in 1884 to extricate some of her men from Sudan, the Mahdi army captured and beheaded him. After a decade, Britain attempted to occupy Sudan under the leadership of Major-General Horatio Herbert Kitchener. Madhi died in 1885 and replaced by his chosen successor and his second-in command, the Khalifa Abdullahi. Using superior weapons such as gunboats, Kitchener defeated the Madhist army at Firket on June 7, 1896. At the battle of Omduruman in 1898, the British army using their superior weapons mowed down the followers of the Mahdi, killed the Khalifa in 1899 and ended the Mahdia Movement. As Vandervort (1998: p. 177) notes, "The many thousands of Mahdists dying and wounded on the battlefield received no aid from the British, who simply turned their backs and marched away. This gives an indication of the depth of feeling in the ranks about the death of Gordon."

Of course, the pacification of different parts of Sudan continued through war and terrorism. For example, when the leader of Darfur in Western Sudan refused to pay taxes, the AngloEgyptian government sent its expeditionary forces and killed 261 and seriously wounded 96 peoples and disbanded about 4,000 soldiers (Herbert, 2003: pp. 188-195). The British had already started to establish their colonies in West Africa and in the early nineteenth century. The Ashanti kingdom between 1823 and 1824 and between 1873 and 1874 challenged this colonial expansion. As Vandervort (1998: p. 84) asserts, "Britain found herself locked in a dispute on the Gold Coast of West Africa with the kingdom of Ashanti, one of the great empires of pre-colonial Africa. The subsequent Anglo-Ashanti war was Britain's first major conflict in the rain forests of tropical Africa." The founding of European trading posts on the shores of the Gold Coast (now Ghana) contributed to the wealth and power of the Ashanti kingdom. This African kingdom was involved in the criminal trade of slavery. According to Vandervort (1998: p. 85), "By the 1680s... slaves accounted for some 75 percent of regional exports. Ashanti military activity during this period was geared closely to seizing slaves for sale to the Europeans, who had begun setting up trading posts like Cape Coast Castle or Accra along the Gold Coast." Despite the fact that the British claimed to own Cape Coast Castle, Ashanti asserted sovereignty on the coastal area. Since the British did not want to recognize Ashanti sovereignty, the relationship between the kingdom and the British officials was broken in 1823. In 1824, an Ashanti army killed General Sir Charles McCarthy and beheaded him; the defeat of the British army led to "the greatest failure in the history of the British occupation of the Gold Coast" (quoted in Vandervort, 1998: p. 85).

In 1871, when the British purchased the littoral of the Gold Coast from the Netherlands, the Ashanti kingdom claimed it as part of its empire. Vandervort (1998: p. 87) notes that the Dutch recognized Ashanti's sovereignty over its enclave of Elmina "whose African inhabitants were loyal subjects of Kumasi, was a vital Ashanti outlet to the sea, where Ashanti merchants could trade directly with foreign suppliers of guns, gunpowder and iron rods (which were cut up to make bullets). In order to preserve the status quo in the former Dutch ports, King Kofi had demanded British recognition of Ashanti sovereignty over the coastal enclaves and payment of annual rent." The refusal to accept the demand of the Ashanti Kingdom led to war between 1873 and 1874 . This time mainly because of its artillery and breech-loaders, the British force defeated the Ashanti army and left "Heaps of dead and wounded." The British army had continued to terrorize the Ashantis since they continued to resist British occupation. "Invaded by an army composed largely of African troops from Nigeria and Central Africa," Vandervort (1998: p. 101) writes, "with a sprinkling of Sikhs, the Ashanti gave the British 'their last as well as the hardest battle the latter had ever fought in their longstanding attempts to control and finally subjugate Ashanti."' The British also gradually established their colonial administration in southern Nigeria and expanded to the north. Lugard declared war on Northern Nigeria known as Hausaland particularly on Kano and Sokoto kingdoms. As the people resisted British colonialism in Hausaland, the British force increased its brutality and terrorism. For example, when Dan Makafo, a religious leader, rebelled in March 1906 in Sokoto, the British mowed down 2000 men and tried the rebel leader; "some other prisoners were killed and their heads cut off and placed on spikes; the village of Satiru was razed to the ground" (Herbert, 2003: p. 52). "The continuing legacy of colonial occupation is an artificial amalgam of some 250 [ethnonational groups] in 30 states," Herbert (2003: p. 56) writes, "Speaking some 400 languages, under a military government dominated by the northern Fulani-Hausa favored by the British civilian and military authorities."

The impacts of colonial terrorism were more devastating in the colonial territories of Germany and Belgium. In 1884, Germany proclaimed a protectorate and started its conquest of Southwest Africa (now Namibia) in 1885 with the arrival of imperial commissioner, Heinrich Göring. Southwest Africa belonged to the Herero, the Nama, and the Damara peoples. In 1893, 200 German troops staged a surprise attack on the Nama town of Hornkranz because Hendrick Witbooi, the leader of Nama refused to recognize German authority. But Witbooi submitted after 18 months of resistance after some of his people was murdered. The German colonial governor, Theodor Leutwein, had a plan for the indigenous peoples; his prediction was that " 15 years from now, there will not be much left for the natives" (quoted in Kiernan, 2007: p. 381). Edwin Herbert (2003: p. 117) describes that "from 1904 to 1907 first the Herero and later the Nama fought an outstandingly brave, initially vicarious, but ultimately tragic battle against their German overlords. The spark that ignited the fire was the action of the Germans in desecrating the old burial place of the Herero chiefs at Okahandja by cutting down the sacred trees and turning the place into a vegetable garden." The Germans saw the indigenous peoples as inferior human beings, drove them from their lands, and destroyed their leadership and their way of life 
(Vandervort, 1998: p. 197). General Lothar von Trotha, the commander the German forces, proclaimed the following: "no war may be conducted humanely against nonhuman... It was and is my policy to use force with terrorism and even brutality. I shall annihilate the revolting [ethnonations] with rivers of blood and rivers of gold. Only after a complete uprooting will something emerge" (quoted in Kiernan, 2007: p. 382).

The German troops poisoned water holes to kill the indigenous peoples and their cattle; they also pushed the Hereo into the Omaheke Desert so that they would die of thirst. On August 11,1904 , the German troops "began 'indiscriminate killing of the wounded, male prisoners, women and children'. Herero causalities quickly reached 5000 killed and 20,000 wounded... German units seized the water holes, forcing the surviving 50,000 Herero to head into the Omaheke Desert. The pursuing German troops massacred almost everyone they found, including women and children, and poisoned the water holes in the desert... By the end of September, the Germans had 'effectively destroyed most of the Herero people"” (Kiernan, 2007: p. 383). Jan-Bart Gewald (2004: pp. 59-60) expounds that "The German settlers and soldiers carried out a shoot-to-kill policy, conducted extrajudicial killings, established concentration camps, employed forced labor, and in at least two cases established death camps." While resisting German colonialism, the Herero were exposed to "a typhus outbreak, a locust plague, and drought killed 10,000 Herero, and a rinderpest epidemic wiped out 80 percent of their cattle herds" (Kiernan, 2007: p. 381). General Trotha issued an 'Extermination Order" on October 2, 1904 by proclaiming the following: "The Herero people must leave this land. If it does not, I will force it to do so by using the great gun [artillery]. Within the German border every male Herero, armed or unarmed, with or without cattle, will be shot to death. I shall no longer receive women or children, but will drive them back to their people or have them shot at. These are my words to the Herero people" (quoted in Kiernan, 2007: p. 383).

The Germans annihilated the indigenous peoples, destroyed their institutions, and took over their homelands. According to Ben Kiernan (2007: p. 386), "The destruction of the Herero proved to be the opening genocide of the twentieth century. Among the three main Southwest African ethnic groups, totaling 125,000 people before 1904, German repression took approximately 80,000 lives in three years, at a cost of 676 German dead, 907 wounded, and 97 missing." The German soldiers and settlers engaged in "extreme acts of violence and cruelty, and they sought, shot, beat, hanged, starved, and raped Herero men, women, and children... no fewer than 80 percent of the Herero had lost their lives. Those who remained in Namibia, primarily women and children, survived in concentration camps as forced laborers employed on state, military, and civilian projects" (Gewald, 2004: p. 60). Using terrorism and genocide, German imperialism crushed these indigenous peoples: "When a census was taken in 1911, only half of the Nama estimated a decade before $(9800$ out of 20,000$)$ and less than a quarter of the Herero $(15,000$ out 80,000$)$ were found to have survived the war. Those who survived had little choice but to become laborers on European-owned farms" (Herbert, 2003: p. 129). In 1898, the Germans established their East African colony (now Tanzania, Rwanda, and Burundi). The movement known as the Maji Maji Rebellion emerged in Tanzania between 1905 and 1906. This rebellion was initiated by the Ngion, a branch of Zulu nation, in the west and the Mattumbi in the east. According to Herbert (2003: p. 130), "The Ngoni had a particular grudge against the Germans due to the execution of some of their chiefs, and the Matumbi had suffered constant demands for forced labor in the cotton fields, which had badly affected their own subsistence farming." The Germans reacted excessively and brutally as in Southwest Africa; their "starvation policy resulted in the death of an estimated 100,000 Africans and the south of the colony became a vast smoking ash heap".

Three German columns went to the rebellious areas in 1905 and burned villages, destroyed crops, and caught and hanged rebellious leaders (Vadervort, 1998: p. 203). The Germans annihilated thousands of indigenous people through war, terrorism, disease, and famine. Some areas "once densely inhabited, reverted to their natural state and in due course became the largest game park in the world" (Herbert, 2003: p. 135). From 250,000 to 300,000 people were decimated by starvation as a result of the Maji Maji Rebellion (Vadervort, 1998: p. 203). Similarly, in West Africa, Germany occupied Togo and Cameroon and practiced similar policies. Two Cameroon kings, King Bell of Douala and King Akwa "agreed to give up their sovereignty [their lands at the mouth of the Cameroon River] under a treaty signed on July 1884 with the German Imperial Consul-General for the west coast Africa" (Herbert, 2003: p. 136). However, the Germans started to carry out the occupation of the entire country moving into the north and interior between 1895 and 1907. Since the indigenous peoples of Cameroon did not make any concession with the Germans, they opposed colonialism and fiercely resisted. Leaders such as Zubeiru organized militia, but his force was defeated and slaughtered (Herbert, 2003: p. 138). Consequently, the Fulani power in north Cameroon was defeated and their leaders were executed or jailed or exiled, and the Germans established their rigid control (Herbert, 2003: p. 138). The Germans executed King Manga Bell and King Joja and others accusing them for inciting rebellions. Through terrorism, brutality, and harshness, the German army reduced the remaining population into coerced workers for German traders and planters. German terrorism was similar to that of Belgium in the Congo.

Between 1890 and 1910, the worst of bloodshed occurred in the Congo under the Belgium colonial administration. The Belgium colonial terrorism caused "one of the great mass killingsof recent history"; it was also "the vilest scramble for loot that ever disfigured the history of human conscience" (quoted in Hochschild, 1998: pp. 3-4). King Leopold II initiated his colonization of the Congo calling it the magnificent African cake through his agent Henry Stanley, an American explorer, between 1880 and 1884. According to Vandervort (1998: p. 137), in 1885 "A makeshift administration was established at Boma, near the mouth of the Congo, and an army, called the force Publique created in 1886 to assist in the 'effective occupation' of the king's vast domain." The Force Publique secured food and labor force, such as porters, through terrorism and other forms of violence to exploit and make the Congo profitable. First of all, the colonial state wanted porters "to collect ivory, set up new posts, put down a rebellion... to carry everything from machine-gun ammunition to all that red wine and pâté. These tens of thousands of porters were usually paid for their work, if only sometimes the food necessary to keep them going, but most of them were conscripts. Even children were put to work: one observer noted seven-to nine-year olds each carrying a load of twenty-two pounds" (Hochschild, 1998: p. 119). As 
Vandervort (1998: p. 145) notes, "The biggest problem faced by the companies and state officials involved in developing the Congo was the securing of labor. Since the Africans did not seem eager to volunteer their services, the king's administrators in Boma stepped in to help. They instituted a system of forced labor, under which Africans were rounded up by the Force Publique and turned over to special African overseers called sentilles who enforced work quotas with shotguns and rhinoceros-hide whips." Another way of recruiting labor was by imposing heavy taxes in cash, and when the Africans failed to pay in cash demanding them to pay in kind such as natural rubber, palm nuts, or ivory. According to Vandervort (1998: p. 145), "If the Africans resisted, as some did, they received a visit from the Force Publique, which often burned the villages, killed women and children, and took away the men as slaves. Africans who failed to meet their quotas - and the quotas were often set unrealistically high - were whipped or, in some highly-publicized cases, had their hands lopped off."

Leopold made a number of royal decrees from Brussels; the first decree was made in 1885 declaring the existence of the Conge Free State and "that all 'vacant land' was the property of the state. There was no definition of what made land vacant" (Hochschild, 1998: p. 117). In the first decree he claimed the ownership of all land and its resources and products. He also made another decrees to lease the vacant and non-vacant land to private companies for long periods. Leopold deployed troops and government officials as well as investment funds to dominate business. His forces terrorized and coerced the Africans to gather ivory and wild rubber while claiming that he "was not to make a profit, but to rescue these benighted people from their indolence" (Hochschild, 1998: p. 118). In the early 1890s, Leopold made ivory gathering and seizing his main goal. In addition to ivory, wild rubber became the main source of revenue after the late 1890s from the Congo. As the need for more labor increased to collect rubber, the labor recruitment system was more militarized. Force Publique officers took hostages of women, children, elders or chiefs. The hostage taking, the cutting of noses and ears, and the severing of hands were deliberate policies. "If a village refused to submit to the rubber regime, state or company troops or their allies sometimes shot everyone in sight, so that nearby villages would get the message.... As the rubber terror spread throughout the rain forest, branded people with memories that remained raw for the rest of their lives" (Hochschild, 1998: p. 165). Whipping also imposed terror by the Chicotte. The authorities sanctioned terror and permitted each capita, an African foreman to administer the bulk of Chicotte to torture bodies of other Africans. The administration of Chicotte "created a class of foremen from among the conquered, like the kapos in the Nazi concentration camps and the predurki, or trusties, in the Soviet gulag" (Hochschild, 1998: pp. 122-123). Force Publique soldiers or Rubber Company "sentries" often killed thousands of Africans.

Missionaries, members of the Force Publique and other witnesses documented about cutting of hands and private parts of men, killing of children and women, hanging of people, mass murder, and cutting of heads. Starvation, exhaustion, and exposure to all forms of violence decimated hundreds of thousands of people. Hunger, starvation and diseases killed more than did bullets; Europeans brought diseases for which Africans did not build up immunities. All these factors resulted in the decrease of the birth rate. Several sources testify that during the Leopold period and its immediate aftermath, the Congo Free
State lost almost half of its population, which was approximately ten million. The death of King Leopold in 1910 brought change and continuity in the Belgium colonial system. The king died a billionaire. Belgium wanted to continue to extract more wealth form the Conge Free State. It took over the Congo and replaced wild rubber with cultivated rubber and introduced a new method of forcing people through taxes: "The imposition of a heavy head tax forced people to go to work on the plantations or in harvesting cotton, palm oil, and other products - and proved an effective means of continuing to collect some wild rubber as well" (Hochschild, 1998: p. 278). The Africans also mined copper, gold, and tin. Because of the lack safety conditions, several thousands of mine workers died; for instance, "in the copper mines and smelters of Katanga, five thousand workers died between 1911 and 1918" (Hochschild 1998: p. 279). The demand for uranium and rubber increased the suffering of Africans: "With the start of the Second World War, the legal maximum for forced labor in the Congo was increased to 120 days per man per year. More than 80 percent of the uranium in the Hiroshima and Nagasaki bombs came from the heavily guarded Congo mine of Shinkolobwe. The Allies also wanted ever more rubber for the tires of hundreds of thousands of military trucks, Jeeps, and warplanes."

Some of the rubber came from the Congo's new plantations of cultivated rubber trees. But in the villages, Africans were forced to go into the rain forest, sometimes for weeks at a time, to search for wild vines once again (Hochschild, 1998: p. 279). In 1960, the Congo achieved its flag independence. Generally speaking, there was no any part of Africa that did not face colonial terrorism. Even the peoples who were brought under the neo-colonial states of Abyssinia (now Ethiopia) and Liberia had suffered from colonial terrorism like other Africans. With the support of England, France, Italy, Abyssinia/Ethiopia created its own empire by colonizing and terrorizing peoples such as Oromos, Somalis, and Sidamas (Holcomb \& Ibssa, 1990; Jalata, 2005). The Ethiopian colonial terrorism and genocide that started during the last decades of the 19th century still continue in the 21 st century. During Ethiopian colonial expansion, Oromia (the Oromo country), "the charming Oromo land, [would] be ploughed by the iron and the fire; flooded with blood and the orgy of pillage" (De Salviac, 2005: p. 349). Calling this event as "the theatre of a great massacre," Martial De Salviac (2005: p. 349) states, "The conduct of Abyssinian armies invading a land is simply barbaric. They contrive a sudden irruption, more often at night. At daybreak, the fire begins; surprised men in the huts or in the fields are three quarter massacred and horribly mutilated; the women and the children and many men are reduced to captivity; the soldiers lead the frightened herds toward the camp, take away the grain and the flour which they load on the shoulders of their prisoners spurred on by blows of the whip, destroy the harvest, then, glutted with booty and intoxicated with blood, go to walk a bit further from the devastation. That is what they call 'civilizing a land'."

The colonization of Oromia involved human tragedy and destruction: "The Abyssinian, in bloody raids, operated by surprise, mowed down without pity, in the country of the Oromo population, a mournful harvest of slaves for which the Muslims were thirsty and whom they bought at very high price" (De Salviac, 2005: p. 28). The Ethiopian forces reduced the Oromo population from 10 to 5 million (Bulatovich, 2000). The surviving Oromos who used to enjoy an egalitarian democracy known as the gadaa system (Oromo democracy) were forced to face 
state terrorism, political repression, and an impoverished life. Alexander Bulatovich (2005: p. 21) applied to Oromia the phrase "flowing in milk and honey" to indicate its abundant wealth in cattle and honey. As France, England, and Italy helped Ethiopia to colonize Oromia and other peoples, successive hegemonic powers, namely England, former USSR and the US have supported and maintained successive Ethiopian governments. Currently, China also supports the authoritarianterrorist regime of Ethiopia (Jalata, 2005). Similarly, with the help of the United States, Americo-Liberians colonized and terrorized the indigenous Liberians (Sundiata, 2003). The first African Americans settled in what is today called Liberia in 1822; they settled in Cape Mesurado where local peoples did not yet form a strong political organization to defend themselves (Gershoni, 1985: p. 5). The American Colonization Society (ACS) that was mainly organized by powerful whites to remove freed Blacks from the United States planned, organized, and settled these Black immigrants (Tyler-McGaw, 2007). In 1824, with the help of the United States the ACS developed an administrative framework for a colony named Liberia, its capital Monrovia. This political structure emerged as the Republic of Liberia in June 1847. Liberia "operated more or less as an American protectorate" (Sundiata, 2003: p. 10).

Unfortunately, Americo-Liberians brought with them racist beliefs and practices that they learned in the United States; they propagated the idea of spreading Christianity and Western civilization (Beyan, 2005): "Imbued with feelings of superiority, they treated the indigenous population with contempt, even those Africans who did convert to Christianity" (Gershoni, 1985: p. 22). Americo-Liberians established a colonial administrative system on the Liberian hinterland, and imposed their authority through war and terrorism: "The reign of terror, exploitation, and humiliation which characterized the rule of two of Liberia's more notorious commissioners... eventually pushed the northern chiefdoms into an all-out revolt" (Gershoni, 1985: p. 88). The Liberian government imposed taxes and introduced coerced labor. It agreed in 1914 with the Spanish colonial government in Spanish Guinea to export coerced laborers by receiving $£ 5$ per head (Sundiata, 2003: pp. 80-81). The violent of overthrow the government dominated by Americao-Liberians did not bring peace to this troubled country, and war and terrorism continued until the early twenty first century (Moran, 2006).

\section{Indigenous Australians and Their Destruction}

With the expansion of European-dominated capitalist world system to the Australian continent in the late nineteenth century via colonialism, the English settlers started terror and genocide on indigenous Australians to expropriate their economic resources and to take-over their homelands. These crimes against humanity had continued in the nineteenth century until the indigenous Australians were almost destroyed and the ownership of their lands was entirely transferred to the English colonial settlers and their descendants. Before their colonization and destruction, the indigenous Australians were organized in families, clans, kinship networks, and ethno-national groups. According to John Mulvaney (1981: p. 18), these social networks frequently coalesced "on occasions when seasonal conditions permitted or when kinship obligations required. Hundreds of individuals often congregated for ceremonial activities such as initiation rituals, and for reciprocal gifts or marriage exchange."
The smaller social groups, such as the family, extended families, the patrilineal or matrilineal descent group, and clans were the effective economic, social, and political units (Cranstone, 1973: p. 32). The indigenous Australians did not engage in war to capture territory or to dominate others; there was small-scale fighting for reasons connected with magical killings, revenge expeditions, with disputes about women, and with trespassing on hunting grounds or sacred places (Cranstone, 1973: p. 32). The European colonialists started to contact and dismantle the social structures of these peoples.

King George III of England instructed Captain Cook on August 22, 1770 to claim the possession of the east coast of Australia that was later named New South Wales. The first British colonial fleet led by Captain Arthur Philip reached at Botany Bay between 18 and 20 January 1788. These English colonialists found that Botany Bay was unsuitable for settlement, and hence they moved to north to Port Jackson on January 26, 1788 and camped at a cove called Cadi by the Cadigal people. They traded food with the indigenous people. Richard Broome (2002: p. 26) states that the English colonized Australia beginning on January 26, 1788 when "ships containing 290 seamen, soldiers and officials and 717 convicts sailed into Port Jackson, to confront the Gamaraigal people of the Sydney area." The second fleet arrived in 1790 with needed food and other supplies. George Vancouver started the process of British colonialism in Western Australia in 1791 by claiming the Albany region in the name of King George III. Tasmania was occupied between 1803 and 1825, Western Australia in 1827, South Australia between 1836 and 1842, Victoria in 1851, and Northern Territory in 1825. England sent to Australia over 162,000 convicts in 806 ships between 1788 and 1850 to colonize the continent. Mathew Flinders suggested the name Australia and later it was adopted as the name of this country. Australia emerged in 1901 as a federation of the six English colonies. The English settlers and indigenous peoples initially exchanged items such as food, cloth, artifacts, and other supplies in amicable and understanding ways. The indigenous Australians initially did not resist the British invaders who were arriving in Australia. As Richard Broome (2002: p. 40) argues, "Had they known the implications the arrival of these strangers would have for their future, they may have met the intruders more frequently with violence and less with curiosity. The irony was that the Aborigines had often helped the European explorers and the first settlers as they bumbled through the bush loaded down with equipment and plagued by inexperience."

Despite the fact that the indigenous peoples never tried to harm these invaders at the beginning, the invaders turned their cooperation and friendly relationship into conflict, war, and terrorism in order to expropriate the homelands of these peoples. Gradually the indigenous peoples realized that the English settlers were expropriating their lands and other resources upon which they depended and disturbed their ways of living. Consequently, between 1790 and 1810, the Eora group in the Sydney region initiated the campaign of resistance against the English invaders in a series of attacks under the leadership of Pemulwuy. According Michael Cannon (1993: pp. 1-2), "The white newcomers were determined that the whole continent of Australia should belong to them-the soil, the beasts and birds, the rivers and fish, the minerals and trees. A dream of total possession had taken hold of normally stolid men. Such lust for new lands ran through the whole British race that monarch and lowliest laborers alike glowed with the glory of creating a new 
empire." The more the settlers expropriated the native lands and destroyed their means of survival, the more the indigenous population groups engaged in resistance. The settlers interpreted the resistance "as barbarous opposition to the enlightened forces of white civilization" (Cannon, 1993: p. 169). The English colonizers and their descendants called indigenous Australians Aborigines by giving them a new name that had no meaning for peoples who had their own ethno-national group names. For the English setters the name Aborigines characterized the backwardness, inferiority, and otherness of indigenous Australians. This name was invented to create a racial boundary between white Europeans and black Australians for dehumanizing the later (Prum et al., 2007: p. 1)."

Once the indigenous Australians were objectified and dehumanized it became easier to terrorize and kill them: "Massacres of Aborigines were usually the work of groups of settlers or colonial police, and less often military units, sometimes in a part-time or volunteer capacity. But... killings could occur with impunity in an ideological atmosphere that mixed expansionism, racism, and classical models with a fetish for cultivation and contempt for indigenous land use" (Kiernan, 2007: p. 252).The Australian colonial government used eugenics and socialDarwinist ideology to legitimize a series of racist policies and colonial terrorism on indigenous Australians. To dispossess the rights of indigenous Australians to life and property, this colonial government developed "classification schemes allegedly proving the inferiority of the native populations living on the territory they conquered" (Prum et al., 2007: p. 2). The English settlers considered the Australian continent "a paradise on earth, for here laid one of the fairest domains ever created by nature. Permanent life-giving rivers meandered through its extensive plains; lush grasslands and forests flourished on its rich soil. The white men could scarcely believe their luck, as they penetrated further into undulating pastures and negotiable bushlands" (Cannon, 1993: p. 10). The British settlers used the doctrine of terra nullius to expropriate native lands through violence; according to this doctrine, Australia belonged to no one and since the indigenous peoples did not have concept of law of ownership, they did not have rights to land. "The continuing pressure of agrarian ideology even when actual settlement patterns were pastoral took on new virulence with spread of scientific racism," Ben Kiernan (2007: p. 309) writes, "which justified mass murder of indigenous communities to safeguard investments in animal stock".

As hunters and food-gatherers, the land use of indigenous peoples was different from a European way of land use in Australia. The British colonizers used this as pretext in confiscating the land of indigenous peoples calling it terra nullius, free waste-land for taking. These activities involved "multiple deliberate killings and a series of genocidal massacres" (Kiernan 2007: p. 250). "As killing escalated, racial justification did, too"; colonial officers said, "disgrace would it be the human race to call them Men" (Rowley, 1972: p. 275). Colonial terrorism in Australia involved the destruction of the essential foundation of the lifestyles of indigenous peoples in economic, political, social, cultural, biological, physical existence, religious, and moral arenas. The English settlers confiscated land and other economic resources and obliterated indigenous institutions of self-government by replacing them with the structures of colonial governments and by repressing cultural and knowledge systems, by reducing quality of food and depriving basic nutrients and causing physical debilitation and death, by en- gaging in mass killings of intellectual and resistance leaders, by destroying indigenous religions, and by undermining moral and ethical values. The English settlers promoted the idea of a White Australia and the extinction of indigenous Australians; the native "land was declared desert and uninhabited later represented as terra nullius and the various nations declared uncivilized". The English setters gradually decimated indigenous population groups, obliterated their cultures, and challenged their survival and identity (Bourke, 1998: p. 40). Genocide can occur in many ways: "The end may be accomplished by the forced disintegration of political and social institutions, of the culture of the people, of their languages, their national feeling and their religion. It may be accomplished by wiping out all [bases] of personal security, liberty, health and dignity" (quoted in Moses, 2004: p. 21).

The indigenous peoples did not understand why the English settlers expropriated their lands and claimed private ownership on them. For instance in 1843, Yagan, an indigenous man, told the advocate general of Victoria the following: "Why do you white people come in ships to our country and shoot down poor black-fellows who do not understand you-you listen to me! The wild black-fellows do not understand your laws, every living animal that roams the country, and every edible fruit that grows in the ground are common property.... For every black man you fellows shoot, I will kill a white man" (quoted in Kiernan, 2007: p. 289). Colonial governors ordered their troops to kill indigenous people and to kidnap their children as unpaid laborers; they ordered their troops to strike the blacks with terror or teach them by terror (Kiernan, 2007: pp. 254-273). One English juror called indigenous Australians "a set of [monkeys] and the earlier they are exterminated from the face of the earth better" (Kiernan, 2007: p. 286). The indigenous peoples were "shot down like dogs while sleeping round their fires, their women taken from them to gratify the lusts of white men, hunted and persecuted in all directions, and in fact looked upon as savage beasts of the forest, whom it was necessary to get rid of, no matter how" (quoted in Kiernan, 2007: p. 278).

The English settlers used several mechanisms of terrorism and genocide against the indigenous Australians, and justified them with racist discourse. These mechanisms included shooting, burning, disease, rape, ethnocide or cultural destruction. A. Drik Moses (2004: p. 27) used the term called "indigenocide" to explain "the intentional invasion/colonization of land; the conquest of the indigenous peoples; the killing of them to the extent that they can barely reproduce themselves and thereby come close to extinction; their classification as vermin by invaders; and the attempted destruction of their religious systems. Indgenocide "is a means of analyzing those circumstances where one, or more peoples, usually immigrants, deliberately set out to supplant a group or groups of other people whom as far as we know, represent the Indigenous, or Aboriginal peoples of the country that the immigrants usurp" (Moses, 2004: p. 21). The English settlers divided the indigenous Australians in order to turn them on one another. The colonial government created the "Native Police Force" by providing food, money, uniforms, horses, and guns to motivate some opportunistic elements to fight against and kill their own people (Broome, 2002: pp. 48-49). Furthermore, they used diseases like smallpox, measles, and tuberculosis killed several thousands of indigenous people. The settlers used food poisoning to kill blacks; they distributed poisoned flour to commit premeditated murder (Broome, 2002: p. 46). Biological warfare was also used in 
colonies such as New South Wales, particularly at Port Jackson in 1789 (Kociumbas, 2004: pp. 80-81).

The colonialists and English scholars tried to minimize the effects of colonial shooting and poisoning on indigenous Australians; they argued that indigenous Australians died out because of their inability to adapt to a changing socio-economic environment. Jan Kociumba (2004: p. 82) comments that "by dwelling on smallpox and other infectious diseases as faceless killers, colonialists and historians directed attention away from more overtly murderous acts such as shooting and poisoning. In particular, the 1789 epidemic laid the foundation for the notion that Aboriginal people were not killed outright, but owing to their own personal weaknesses and cultural flaws, sadly just 'faded away'. It was as if smallpox was nothing more than the first stage in the tragic but necessary workings of evolutionary law, annihilating all species slow to 'adapt'." In their political discourses, the colonialists and their apologists blamed the conflicts among indigenous people, lack of healthy conditions, and the behavior of indigenous peoples for the destruction of indigenous communities. While openly engaged in exterminating the indigenous peoples, the settlers and their descendants have also argued, "indigenous society was not destroyed by the Europeans, but collapsed under the weight of its own pathologies" (Moses, 2004: p. 15). In other words, they have suggested that it was not the English settlers and their violence that destroyed indigenous communities, but the indigenous communities themselves caused their own destruction: "Coupled with emphasis on intertribal killings, alcoholism, unhygienic living conditions and, more recently, deaths in police custody, the result has been to blame the victims of their own demise" (Kociumbas, 2004: p. 82).

The settlers raped women or slaughtered and massacred women, children and the aged (Broome, 2002: p. 46). They also kidnapped young children to satisfy their demand of labor for housework and harvesting (Kociumbas, 2004: p. 92). Since there were no rich mines and manufacturing industries in Australia, "the settlers had never wanted much from Aboriginal people except their women and their land; for labor the settlers mainly depended on convict labor and imported coolies" (Kociumbas, 2004: p. 92). Rape was also used as a mechanism of terror to destroy indigenous families and communities. Some settlers held indigenous women and small girls and used them for sexual gratification (Broome, 2002: p. 45). As the brutal dispossession of land increased in the early nineteenth century in the continent, colonialists and scholars claimed that" indigenous survivors were not really people at all" (Kociumbas, 2004: p. 96). Colonial officials justified the total extermination of indigenous peoples by calling them non-human beings. They proclaimed that "let us at once exterminate these useless and obnoxious wretches" (Moses, 2004: p. 15). The English settlers also engaged in trade in body parts of indigenous peoples for scientific purposes. Medical schools and scientific societies in Europe were interested in both living and dead specimens; they purchased skeletons and skulls, too (Kociumbas, 2004: p. 97). According to Jan Kociumbas (2004: p. 98), "“The fact that Australia's indigenous peoples were so extensively dismembered and exhibited as scientific freaks made for a particularly virulent form of racism, which rendered it increasingly impossible for even model, educated Aboriginal people to find acceptable in settler society. Men became extremely vulnerable to capital conviction of rape against white women, though white men continued to rape Aboriginal women virtually as a right." It is disturbing to realize that one human group used modern education, technology, and legal means to hide the crimes against humanity: "What is unique about genocide in Australia is not its violence, but its apparent legality and above all its modernity. It was modern technology that made possible the pace and effectiveness of the killing, and modern law that provided the judicial niceties that condoned it. It was modern education, not colonial ignorance that helped create the conditions where official silence and legally-sanctioned cover-ups could prevail" (Kociumbas, 2004: pp. 98-99).

\section{Discussion and Conclusion}

The descendants of colonizers in the Americas, Australia, and Africa, and powerful European nations of today should realize that originally the lands and other resources of the indigenous peoples mightily contributed to their processes of wealth accumulation, power, and knowledge and start to think ways of recognizing the crimes committed against humanity in these continents and to compensate the surviving indigenous peoples one way of the other. Unfortunately, as Noam Chomsky (1993: p. 32) says, "One of the great advantages of being rich and powerful is that you never have to say: 'I am sorry.' It is here that the moral and cultural challenge arises, at the end of the first 500 years." The majority of European descendants in Europe, the Americas, Australia, and Africa and their collaborators in the rest of the world have difficulties in recognizing the crimes their ancestors committed on indigenous peoples. Jürgen Zimmeere (2004: p. 51) also notes that "The question of colonial genocide is disturbing, in part because it increases the number of mass murders regarded as genocide, and in part, too, because it calls into question the Europeanization of the globe as a modernizing project. Where the descendants of perpetrators still comprise the majority or a large proportion of the population, and control political life and public discourse, recognition of colonial genocides is even more difficult, as it undermines the image of the past on which national identity is built."

Learning from the experiences of colonial war and terrorism in the Americas, Africa, Australia, and other places, the European powers perfected their desire for killings and destruction of human beings. According to V. G. Kiernan (1982: p. 178), "For Europe at large expansion afforded an outlet to impulses of violence, and could relieve internal tensions, but there was always a chance that it might recoil and intensify them instead. If conquest was doing something to civilize the outer world, it was also doing something to barbarize Europe." The consequences of the so-called First and Second World wars testify to this assertion. As far as the West continues to deny the crimes of their ancestors and continue to facilitate war and state terrorism on the rest of the world through its puppet governments in the Global South, the peoples in the West cannot achieve their true and full humanity and peace and promote social justice in the whole world. One cannot maintain his or her humanity while dehumanizing other human beings. Furthermore, the reign of terror that has been imposed on the Rest by the West has produced in some corners of the Rest similar forces that engage in terrorism from below. Since these forces now share information and knowledge with the West and have access to modern weapons, it is not easy to defeat and eradicate them without understanding, addressing, and solving all forms of violence. As V. G. Kiernan (1982: p. 230) puts, “There are, after 
all, good reasons for prying into the past with the historian's telescope and trying to see more clearly what happened, instead of being content with legend or fantasy. Of all reasons for an interest in the colonial wars [and terrorism] of modern times the best is that they are still going on, openly and disguised."

The indigenous communities deserve apologies and reparations. By taking such actions, governments, corporations, dominant societies, and international organizations recognize that there is always price to be paid for the crimes committed against humanity and learn how to avoid such inhumane acts in present time. Successive European and Euro-American-Australian governments and their collaborators in the Global South have not only exterminated indigenous peoples and refused to recognize the crimes they have committed against them, but they have also attempted to commit ethnocide on the survivors by denying them the rights to self-determination, democracy, and human development. Some modern ideologies have justified the degrading of the values of sharing and caring for others regardless of religious beliefs, skin colors, and ethnicity while glorifying Euro-American-Australian cruelty, robbery, terrorism, and genocide. Had the European settlers and their descendants have shared their knowledge and technology and cared for indigenous peoples as the latter initially cared for the former, the world would be built on human centered values that could have promoted multicultural lifestyles rather than EuroAmerican-centric and racist values. In addition, by attacking indigenous cultures and lifestyles, the peoples of European background intentionally dismissed some aspects of their own histories and cultures that existed in Europe prior to the emergence of mercantilist capitalism in which peoples shared and cared for one another although there were oppression and exploitation.

The Euro-Americans-Australians and their descendants have acted as they always had modern knowledge and technology to claim racial and cultural superiority by suppressing their premodern histories and cultures that existed before the sixteenth century. The crimes committed against indigenous peoples in the names of God, commerce, progress, civilization, culture and/or race or religion for making money and acquiring lands should be recognized by the present generation of the previous European settlers and other human groups to understand the historical root of modern human rights violations and to seek a just political solution for existing socio-economic, cultural and political problems of indigenous peoples. All powerful individuals and groups should critically interrogate themselves morally, culturally, socially, and politically in order to develop their humanness rather than hiding their inhumane behaviors and actions under the discourses of modernity, civilization, religion, race or culture and continue to commit similar crimes by engaging or supporting unjust and corrupt political and ideological practices. Engaging in or supporting a system that annihilates human beings is morally, ethically, and intellectually wrong because of ideological and cultural blindness and/or to satisfy the appetite for power and money. By understanding the devastating effects of colonialism its various forms of violence on the indigenous peoples, the present generations of Euro-American-Australian descendants and their collaborators in the Global South should start to uplift the surviving ones by making restitution and by promoting and supporting their struggles for self-determination and multicultural democracy.

All governments and institutions in the West need to stop repeating lies and misinformation about the indigenous peoples by recognizing and incorporating their authentic histories, cultures, and humanity in school and college education. Celebrating the contributions of the indigenous peoples, recognizing the crimes committed and compensating them, and accepting the diversity of all countries will help in fully developing the humanity and the diverse cultural and ethnonational backgrounds by resurrecting the damaged humanity of the executioners and the victims. Without critically understanding the processes of capitalist broadening and incorporation and without adequately learning about the crimes of colonialism and continued subjugation, we cannot confront the moral, philosophical, and political contradictions in the capitalist world system in order to move toward establishing a just and truly egalitarian democratic world order. It is urgent that serious scholars establish a single moral, intellectual, legal, and political position in the study and understanding of the problems of indigenous peoples and suggest pragmatic policies to eliminate or reduce racial/ethnonational inequality, underdevelopment, poverty, and ignorance in the modern world system. Universities should be the center in which these issues should be addressed, debated, and resolved if they are truly interested in promoting and practicing social justice. Humanity should stop to brag about its progress, civilization, scientific revolution, and religions until it goes back and studies its crimes against its weakest elements so that it can critically understand its darkness, barbarism, and falsehood.

The mainstream knowledge elites from right and left have treated the indigenous peoples as historical objects because of their powerlessness. These elites with the support of the nationstates produced "official history" that has completely denied a historical space for the colonized and dehumanized peoples around the world. As M. A. Rahman (1993: p. 4) notes, "domination of masses by elites is rooted not only in the polarization of control over the means of material production but also over the means of knowledge production, including control over social power to determine what is useful knowledge". With their colonization and incorporation into the capitalist world system, the indigenous peoples could not develop independent institutions that would allow them to produce and disseminate their historical knowledge freely. Negative views about the indigenous peoples have prevented the dominant societies from understanding the histories and cultures of indigenous peoples. While colonial elites and their supporters have continued to support the official version of history, indigenous and a few critical scholars have realized the necessity of a plurality of centers in knowledge production and dissemination. A few innovative scholars have recognized the importance of looking at a society from different cultural centers and have developed the emergent indigenous studies. The development of indigenous movements in different parts of the world shows that there are political and economic crises in various nation-states in particular and the global system in general. The development of cultural and social movements among colonized peoples is seen as an integral part of the worldwide struggle for cultural identity, multiculturalism, economic freedom, social justice, and inalienable political and cultural rights of these peoples.

\section{REFERENCES}

Algerĭa, R. (1997). The study of aboriginal peoples: Multiple ways of knowing. In S. M. Wilson (Ed.), The indigenous people of the Caribbean (pp. 9-19). Gainesville, FL: University of Florida. 
Baldwin, J. (1963). A talk to teachers. In R. Simonson, \& S. Walker, (Eds.), Multiculturalism literacy (pp. 3-12). St. Paul, MN: Graywolf Press.

Balibar, E., \& Wallerstein, I. (1991). Race, nation, class: Ambiguous identities. New York: Verso.

Brennan, W. (1995). Dehumanizing the vulnerable: When word games take lives. Chicago, IL: Loyola University Press.

Black, D. (2004). The geometry of terrorism. Sociological Theory, 22, 14-25. doi:10.1111/j.1467-9558.2004.00201.x

Blackhawk, N. (2006). Violence over the land: Indians and empires in the early American west. Cambridge, MA: Harvard University Press.

Blakeley, R. (2009). State terrorism and neoliberalism: The north in the south. New York: Routledge.

Bodley, J. H. (1982). Victims of progress (3rd ed.). Mountain View, CA: Mayfield Publishing Co.

Bodley, J. H. (1992). Anthropology and the politics of genocide. In N. Carolyn, \& J. Martin (Eds.). The paths to domination, resistance and terror (pp. 37-51). Berkeley, CA: University of California Press.

Burns, J. (1988). Canada tries to make restitution to its own. New York Times, 1 September 1992.

Beyan, A. T. (2005). African American settlements in West Africa: John Brown Russwurm and the civilizing efforts. New York: Palgrave. doi:10.1057/9781403979193

Birmingham, D. (1999). Portugal and Africa. New York: St. Martin's Press, Inc.

Birmingham, D. (2006). Empire in Africa: Angola and its neighbors. Athens, OH: Ohio University Press.

Branche, R. (2004). Torture and other violations of the law by the French army during the Algerian War. In J. Adam (Ed.), Genocide, war crimes \& the west (pp. 134-145). London: Zed Books,

Boorstin, D. J. (1983). The discoverers: A history of man's search to know his world and himself. New York: Random House Inc.

Bulatovich, A. (2000). Ethiopia through Russian eyes: Country in transition, 1896-1898. Lawrenceville, NJ: The Red Sea Press.

Broome, R. (2002). Aboriginal Australians: Black responses to white dominance (3rd ed.). Sydney: Allen \& Unwin.

Bourke, E. (1998). Images and realities. In B. Colin, E. Bourke, \& B. Edwards (Eds.), Aboriginal Australia (pp. 1-15). Queensland: University of Queensland Press.

Bourke, E. (1998). Australia's first peoples: Identity and population. In B. Colin, E. Bourke, \& B. Edwards (Eds.), Aboriginal Australia (pp. 38-55), St Lucia, QLD: University of Queensland Press.

Bultin, N. G. (1993). Economics and the dreamtime: A hypothetical history. Melbourne: Cambridge University Press.

Cannon, M. (1993). Black land, White Land. Melbourne: Minerva.

Carlson, J. D. (2001). Broadening and deepening: Systemic expansion, incorporation and the zone of ignorance. Journal of World-Systems Research, 2, 225-264.

Carlson, J. D. (2002). The "otter-man" empires: The Pacific fur trade, incorporation and the zone of ignorance. Journal of World-Systems Research, 8, 390-442.

Chase-Dunn, C. and Thomas D. H. (1997). Rise and demise: Comparing world-systems. Boulder, CO: Westview Press.

Chomsky, N. (1993). Years 5001: The conquest continues. Boston, MA: South End Press.

Clegg III, C. A. (2004). The price of liberty: African Americans and the making of Liberia. Chapel Hill, CA: The University of North Carolina Press.

Cohen, J. M. (1969). Christopher Columbus: The four voyages. London: Penguin Books.

Colson, E. (1992). Conflict and violence. In C. Nordstrom, \& J. Martin (Eds.), The paths to domination, resistance and terror (pp. 277-287). Berkeley, CA: University of California Press,

Coquery-Vidrovitch, C. (1985). French Congo and Gabon, 1886-1905. In J. D. Fage, \& R. Oliver (Eds.), The Cambridge history of Africa (pp. 298-315). Cambridge: Cambridge University Press.

Cranstone, B. A. L. (1973). The Australian aborigines. London: The Trustees of the British Museum.

Cannon, M. (1993). Black land, white land. Melbourne: Minerva.

Davidson, B. (1961). The African slave trade: Pre-colonial history
1450-1850. Boston, MA: The Atlantic Monthly Press.

Davis, M. (2001). Late Victorian holocausts: El Nino famines and the making of the third world. London: Verso.

De Las Casas, B. (1992). A short account of the destruction of the Indies. London: Penguin Books.

De Las Casas, B. (1971). History of the Indies. New York: Harper \& Row.

De Salviac, M. (2005) An ancient people, great African nation. Michigan, MI: East Lansing.

Debo, A. (1995). A History of the Indians of the United States. London: Pimlico Edition.

Den Berghe, P. (1970). South Africa: A study in conflict. Los Angeles, CA: University of California Press.

Deschamps, H. (1985). Madagascar and France, 1870-1907. In J. D. Fage, \& R. Oliver (Eds.), The Cambridge history of Africa (pp. 298-315). Cambridge: Cambridge University Press.

Diamond, J. (1999). Guns, germs, and steel: The fates of human societies. New York: W. W. Norton \& Company.

Dickson, O. P. (2002). Canada's first nations (3rd ed.). New York: Oxford University Press.

Dickson, O. P. (2006). A concise history of Canada's first nations. New York: Oxford University Press.

Do Bois, W. E. B. (1977 [1935]). Black reconstruction. Cleveland, OH: World Meridian.

Dunaway, W. A. (1996). The incorporation of mountain ecosystems into the capitalist world-system. Review, 19, 355-381.

Elder, B. (1988). Blood on the wattle: Massacres and maltreatment of Australian aborigines since 1788. Sydney: New Holland.

Elkins, C. (2005). Imperial reckoning: The untold story of Britain's gulag in Kenya. New York: Henry Holt and Company.

Elkin, A. P. (1951). Reaction and interaction: A food gathering people and European settlement in Australia. American Anthropologist, 53, 164-186.

Evans, R., \& Thrope, B. (2001). The massacre of aboriginal history. Overland, 163, 21-40.

Falola, T. (2002). Key events in African history: A reference guide. Westport, CT: Greenwood Press.

Fenn, E. A. (2000). Biological warfare in eighteenth-century North America. Journal of American History, 86, 552-558.

Fenelon, J. V. (1997). From peripheral domination to internal colonialism: Socio-political change of the Lakota on standing rock. Journal of World-Systems Research, 3, 259-320.

Fenelon, J. V. (1998). Culturicide, resistance, and survival of the lakota ("Sioux Nation"). New York: Garland Publishing, Inc.

Ferguson, R. B., \& Whitehead, N. L. (1992). War in the tribal zone. Santa Fe, NM: SAR Press.

Freund, B. (1984). The making of contemporary Africa. Bloomington, IN: Indiana University Press.

Ganiage, J. (1985). North Africa . In J. D. Fage, \& R. Oliver (Eds.), The Cambridge history of Africa (pp. 159-171). Cambridge: Cambridge University Press

Gershoni, Y. (1985). Black colonialism: The Americo-Liberian scramble for the hinterland. Boulder, CO: Westview Press.

Gewald, J.-B. (2004). Imperial Germany and the herero of Southern Africa: Genocide and the quest for recompense. In J. Adam (Ed.). Genocide, war crimes \& the west: History and complicity (pp. 5977). London: Zed Books,

Goodwin, J. (2006). A theory of categorical terrorism. Social Forces, 84, 2027-2046. doi:10.1353/sof.2006.0090

Grant, K. (2005). A civilised savagery: Britain and the new slaveries in Africa, 1884-1926. New York: Routledge.

Haebich, A. (2004). Clearing the wheat belt: Erasing the indigenous presence in the southwest of Western Australia. In A. D. Moses (Ed.), Genocide and settler society: Frontier violence and stolen indigenous children in Australian history (pp. 267-289). New York: Berghahn Books.

Hall, T. D. (1996). The world-system perspective: A small sample from a large universe. Sociological Inquiry, 66, 440-454. doi:10.1111/j.1475-682X.1996.tb01186.x

Hall, T. D. (1989). Social change in the southwest, 1350-1880. Law- 
rence, KS: University Press of Kansas.

Hall, T. D., \& Fenelon, J. V. (2004). The futures of indigenous peoples: 9-11 and the trajectory of indigenous survival and resistance. Journal of World-Systems Research, 10, 153-197.

Haraway, D. J. (1991). Simians, cyborgs, and women. New York: Routledge.

Hargreaves, J. D. (1985). Western Africa, 1886-1905. In J. D. Fage, \& R. Oliver (Eds.), The Cambridge history of Africa (pp. 259-279). Cambridge: Cambridge University Press

Herbert, E. (2003). Small wars and skirmishes 1902-1918. Nottingham: Foundry Books.

Hollis, S. A. (2005). Contact, incorporation, and the North American southeast. Journal of World-Systems Research, 11, 95-130.

Hochschild, A. (1998). King Leopold's ghost: A story of greed, terror, and heroism in Colonial Africa. New York: Houghton Mifflin Company.

Holcomb, B., \& Ibssa, S. (1990). The Invention of Ethiopia. Trenton, NJ: The Red Sea Press.

Humbaraci, A., \& Muchnik, N. (1974). Portugal's African wars. New York: The Third Press.

Hughes, R. (1987) The fatal shore. London: Random House Inc.

Jalata, A. (2001). Fighting against the injustice of the state and globalization. New York: Palgrave.

Jefferson, T. (1813). Alexander von Humboldt's Correspondence with Jefferson, Madison, and Gallatin. Proceedings of the American Philosophical Society, 103, 792-793.

Josephy, Jr., \& Alvin M., (1991). Introduction: The center of the universe. In American 1492: The world of the Indian peoples before the arrival of Columbus (pp. 3-19). New York: Vintage Books,

Kiernan, B. (2007). Blood and soil: A world history of genocide and extermination from Sparta to Darfur. New Haven, CT: Yale University Press.

Kiernan, V. G. (1982). From conquest to collapse: European empires from 1815-1960. New York: Pantheon Books.

Kociumbas, J. (2004). Genocide and modernity in colonial Australia, 1788-1850. In A. D. Moses (Ed.), Genocide and settler society: Frontier violence and stolen indigenous children in Australian history (pp. 77-102). New York: Berghahn Books.

Kociumbas, J. (2004). Genocide and modernity in colonial Australia, 1788-1850. In A. D. Moses (Ed.), Genocide and settler society: Frontier violence and stolen indigenous children in Australian history (pp. 77-102). New York: Berghahn Books.

Loewen, J. W. (1995). Lies my teacher told me: Everything your American history textbook got wrong. New York: Touchstone.

Lonsdale, J. (1985). The European scramble and conquest in African history. In J. D. Fage, \& R. Oliver (Eds.), The Cambridge history of Africa (pp. 680-766). Cambridge: Cambridge University Press.

Magubane, B. (1996). The making of a racist state: British imperialism and the union of South Africa, 1875-1910. Trenton, NJ: The Red Sea Press.

Magubane, B. (1979). The political economy of race and class in South Africa. New York: Monthly Review.

Malik, K. (1996). The making of race. New York: New York University Press.

Marks, S. (1985). Southern Africa, 1867-1886. In J. D. Fage, \& R. Oliver (Eds.), The Cambridge history of Africa (pp. 359-421). Cambridge: Cambridge University Press

Marx, K. (1967). Capital. New York: International Publishers.

Metcalf, A. C. (2005). Go-between and the colonization of Brazil, 1500-1600. Austin: The University of Texas.

Miller, J. C. (2002). West Africa. In The Atlantic slave trade (pp. 45-51). Boston, MA: Houghton Mifflin Company,.

Moran, M. H. (2006). Liberia: The violence of democracy. Philadelphia, PA: University of Pennsylvania Press.

Moses, A. D. (2004). Genocide and settler society: Frontier violence and stolen indigenous children in Australian history. New York: Berghahn Books.

Mulvaney, J. (1981). Origins. In Aboriginal Australia. Sydney: Australian Gallery Directors Council.

Mulvaney, D. J., \& White J. P. (1987). Australians to 1788. Sydney:
Fairfax, Syme \& Weldon.

Nevinson, H. W. (1906). A modern slavery. London: Haper \& Brothers. Perdue, T. (2005). The cherokees: Indians of North America. Philadelphia: Chelsea House Publishers.

Person, Y. (1985). West Africa, 1870-1886. In J. D. Fage, \& R. Oliver (eds.), The Cambridge history of Africa (pp. 208-256). Cambridge: Cambridge University Press.

Perude, T., \& Green, M. D. (2005). The cherokee removal: A brief history with documents (2nd ed.). New York: Bedford/St. Martins.

Polanyi, K. (1944). The great transformation. Boston, MA: Beacon press.

Prum, M., Deschamps, B., \& Narie-Claude, B. (2007). Racial, ethnic, and homophobic violence: Killing in the name of otherness. New York: Taylor \& Francis Group.

Rahman, M. A. (1993). The theoretical standpoint of PAR [Participatory Action-Research]. In O. Fals-Borda, \& M. A. Rahman (Eds.), Action and knoweldge: Breaking the monopoly with participatory action-research. New York: Apex Press.

Rodney, W. (1972). How Europe underdeveloped Africa. Washington DC: Howard University Press.

Roediger, D. R. (1991). The wages of whiteness. London: Verso.

Rowley, C. D. (1972). The destruction of aboriginal society. Ringwood: VIC: Penguin.

Sanderson, G. N. (1985). The European partition of Africa: Origins and dynamics. In J. D. Fage, \& R. Oliver (Eds.), The Cambridge history of Africa (pp. 96-158). Cambridge: Cambridge University Press.

Schreuder, D. M. (1980).The Scramble for Southern Africa, 1877-1895: The politics of Partition reappraised. Cambridge: Cambridge University Press.

Sharlack, L. (2002). State rape: Sexual violence as genocide. In K. Worcester, S. A. Bermanzohn, \& M. Ungar (Eds.), Violence and politics: Golobalization's paradox. New York: Routledge.

Shiva, V. (1997). Biopiracy: The plunder of nature and knowledge. Boston, MA: South End Press.

Smith, A. (1985). Angola and Mozambique, 1870-1905. In J. D. Fage, \& R. Oliver (Eds.), The Cambridge history of Africa (pp. 493-520). Cambridge: Cambridge University Press.

Stengers, J. (1985). King Leopold's Congo, 1886-1908. In J. D. Fage, \& R. Oliver (Eds.), The Cambridge history of Africa (pp. 315-358). Cambridge: Cambridge University Press.

Sturgis, A. H. (2007). The trail of tears and Indian removal. Westport, CT: Greenwood Press.

Sundiata, I. (2003). Brothers and strangers: Black Zion, black slavery, 1914-1940. Durham: Duke University Press.

Suret-Canale, J. (1964). French colonialism in tropical Africa 19001945. New York: Pica Press.

Thrope, B. (1996). Colonial Queensland: Perspective on a frontier society. Birsbane: University of Queensland Press

Theal, G. M. (1969). South Africa. New York: Negro Universities Press.

Thompson, L. (2001). History of South Africa. New Heaven, CT: Yale University Press.

Thompson, V., \& Adloff, R. (1968). Djibouti and the Horn of Africa. Stanford: Stanford University Press.

Thornton, J. (2002). Warfare and slavery. In D. Northrup (Ed.), The Atlantic slave trade (pp. 55-64). Boston, MA: Houghton Mifflin Company,.

Tindale, N. B. (1974). Aboriginal tribes of Australia: Their terrain, environmental controls, distribution, limits and proper names. Berkeley, CA: University of California Press.

Turok, B. and Maxey, K. (1985). Sothern Africa in crisis. In P. C. W. Gutkind, \& I. Wallerstein(Eds.), Political economy of contemporary Africa (pp. 243-278). London: Sage Publications,.

Tyler-McGraw, M. (2007). An African REPUBLIC: Black \& White Virginians in the making of Liberia. Chapel Hill, CA: University of North Carolina Press.

Vandervort, B. (1998). Wars of imperial conquest in Africa, 1830-1914. Bloomington, IN: Indiana University Press.

Whitehead, N. L. (1993). Ethnic transformation and historical discontinuity in native Amazonia and Guayana, 1500-1900. L'Homme, 33, 


\section{A. JALATA}

285-305.

Whitehead, N. L. (2004a). On the poetics of violence. In N. L. Whitehead (Ed.), Violence (pp. 55-77). Santa Fe, NM: School of American research Press.

Whitehead, N. L. (2004b). Introduction: Cultures, conflicts, and the poetics of violent practice. In N. L. Whitehead (Ed.), Violence (pp. 3-24). Santa Fe, NM: School of American Research Press.

Wilkinson, P. (1979). Social scientific theory and civil violence. In A. Yonah, D. Carlton, \& P. Wilkinson (Eds.), Terrorism: Theory and practice (pp. 45-72). Boulder, CO: Westview Press

Wilson, S. (1997). Introduction to the study of the indigenous people of the Caribbean. In S. M. Wilson (Ed.), The Indigenous people of the
Caribbean (pp. 1-19). Gainesville, FL: University of Florida.

Winant, H. (1994). Racial conditions. Minneapolis, MN: University of Minnesota Press.

Wolf, E. (1981). Europe and the people without history. Berkeley, CA: University of California.

Zimmeere, J. (2004). Colonialism and the holocaust: Towards a archeology of genocide. In A. D. Moses (Ed.), Genocide and Settler Society: Frontier violence and stolen indigenous children in Australian history (pp. 49-76). New York: Berghahn Books,

Zinn, H. (2003). A people's history of the United States: 1492-present. New York: Harper Collins Publishers. 